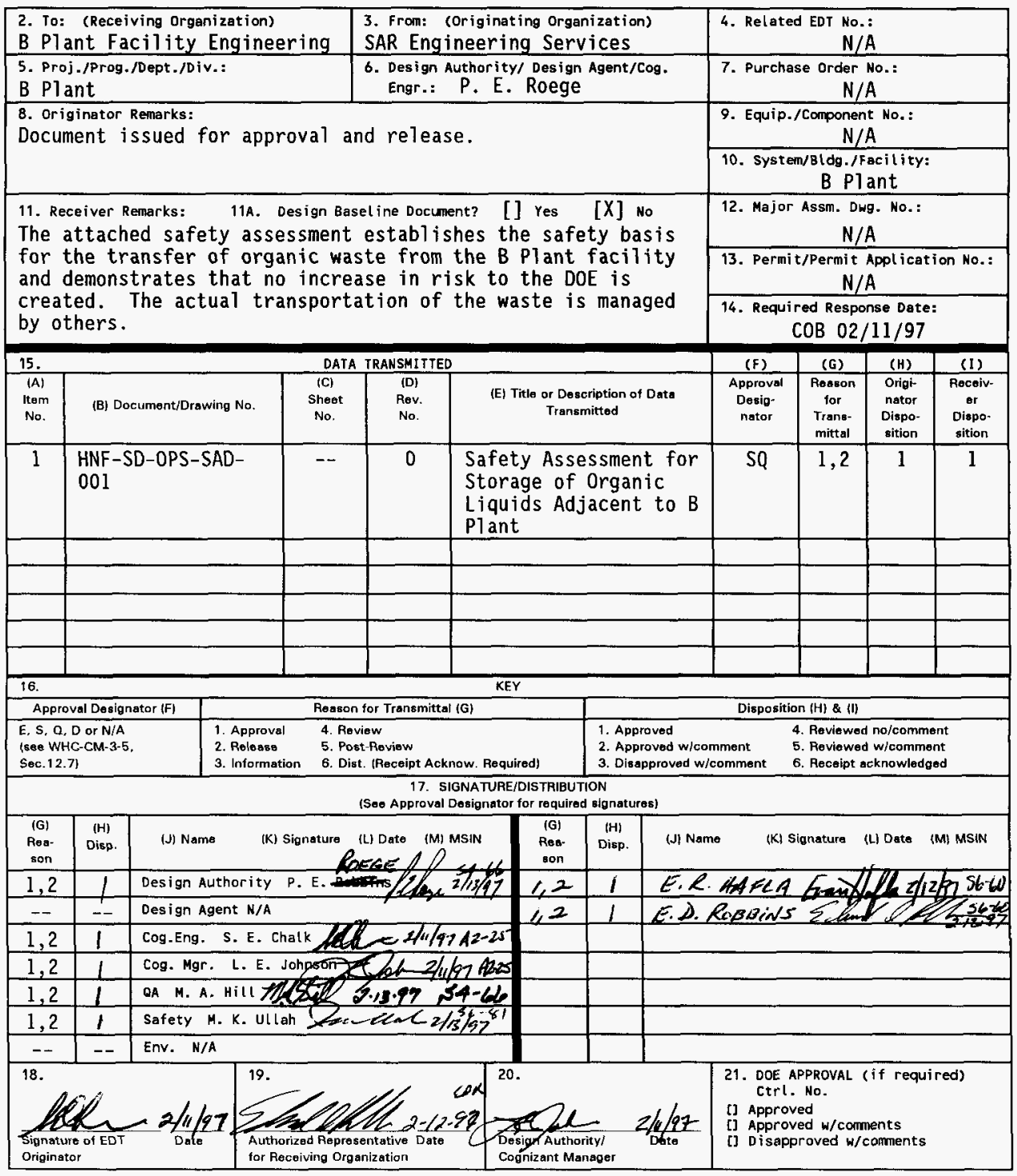

BD-7400-172-2(05/96) GEF097 


\section{Safety Assessment for Storage of Organic Liquids Adjacent to B Plant}

Fluor Daniel Northwest, Richland, WA 99352

Steve E. Chalk

U.S. Department of Energy Contract DE-AC06-96RL 13200

EDT/ECN: 616283

UC: 510

Org Code: 403

B\&R Code: EW7002010 Total Pages: $47432 / 13 / 97$

Key Words: USQ, Organics, Safety, Storage

Abstract: This safety assessment was written to analyze the potential hazards and accidents that could occur during the storage of organic liquid waste outside of the B Plant facility.

IRADEMARK DISCLAIMER. Reference herein to any specific commercial product, process, or service by trade name, trademark, manufacturer, or otherwise, does not necessarily constitute or imply its endorsement, recomendation, or favoring by the United States Government or any agency thereof or its contractors or subcontractors.

Printed in the United States of America. To obtain copies of this document, contact: HHC/BCS Document Control Services, P.O. Box 1970, Mailstop H6-08, Richland WA 99352, Phone (509) 372-2420; Fax (509) 376-4989.
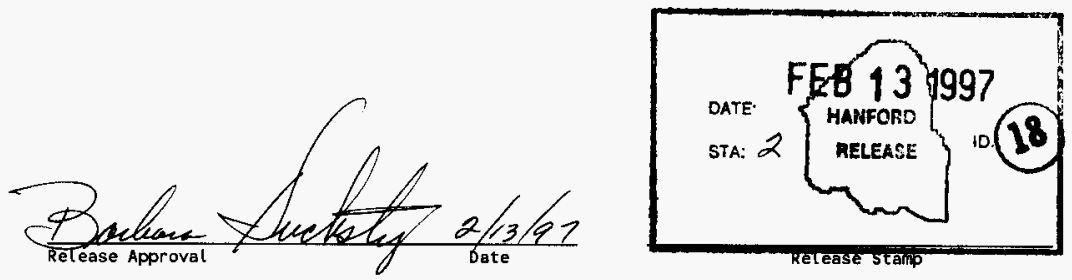

Approved for Public Release 
HNF-SD-0PS-SAD-001, Rev. 0

\section{SAFETY ASSESSMENT FOR STORAGE OF ORGANIC LIQUIDS ADJACENT TO B PLANT}

Prepared By:

Fluor Daniel Northwest

P.O. Box 1050

Richland, WA 99352

For:

B \& W Hanford Company

P.0. Box 1200

Richland, WA 99352

February 1997 
HNF-SD-OPS-SAD-001, Rev. 0

This page intentionally left blank. 


\section{CONTENTS}

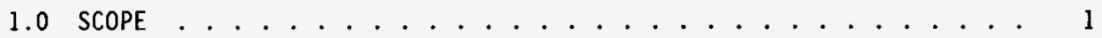

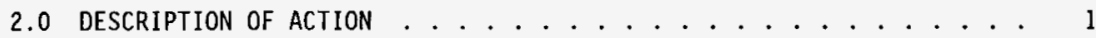

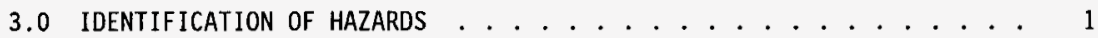

4.0 HAZARDS ANALYSIS ..................... . . . 7

4.1 BASIC APPROACH .................. 7

4.2 LIQUID SPILL AND BURNING SCENARIO ............. . 9

4.3 HYDROGEN GENERATION WITHIN THE TANK ............ 11

5.0 CONSEQUENCE OF ACCIDENTS . . . . . . . . . . . . . 13

5.1 CONSEQUENCE ANALYSIS METHODOLOGY . . . . . . . . . 13

5.2 ORGANIC SPILL AND FIRE (RADIOLOGICAL CONSEQUENCES) $\ldots \ldots .15$

5.3 ORGANIC SPILL AND FIRE (TOXICOLOGICAL CONSEQUENCES) $\ldots \ldots . .17$ 5.3.1 Phosphorous Pentoxide ............ . 17 5.3.2 Carbon Monoxide ............ . 19

5.4 HYDROGEN EXPLOSION IN THE TANK HEADSPACE $\ldots . \ldots . . .20$

5.5 SPILL OF ORGANIC FROM EXTERNAL TANK (RADIOLOGICAL CONSEQUENCES) .................... 21

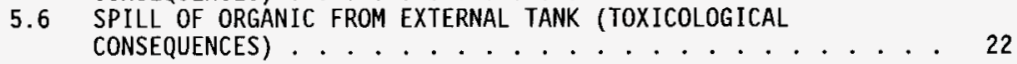

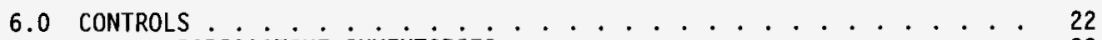

6.1 RADIOACTIVE INVENTORIES . . . ............ 22

6.2 TRANSFER FROM PRIMARY TO SPARE TANK .......... 23

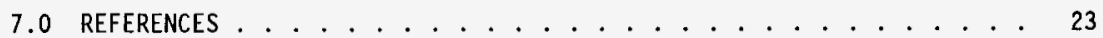

APPENDIX A MATHCAD CALCULATIONS ................... A-1

APPENDIX B PRELIMINARY HAZARDS ANALYSIS (PHA) PARTICIPANTS . . . . B-1 
HNF-SD-0PS-SAD-001, Rev. 0

\section{LIST OF TABLES}

1. PHA Table for Organic Storage Tanks USQ . . . . . . . . . . . . 3

2. PHA Checklist..................... . . 7

3. WHC Risk Acceptance Guidelines . . . . . . . . . . . . . . . . . . 8

4. Maximum ${ }^{90} \mathrm{Sr}$ and ${ }^{137} \mathrm{Cs}$ Quantities (Ci) Prior To Placement of Tank Onto Concrete Pad (Berm Not In Place) . . . . . . . . . . . 8

5. Maximum ${ }^{90} \mathrm{Sr}$ and ${ }^{137} \mathrm{Cs}$ Quantities (Ci) Prior To Placement of Tank Onto Concrete Pad (Berm In Place) . . . . . . . . . . . g

6. Hydrogen Generation Data . . . . . . . . . . . . . . 12

7. Site Boundary Distances Used in Offsite Dispersion Calculations . . 14

8. Atmospheric Dispersion Coefficients $(X / Q S)$ Used in the Accident

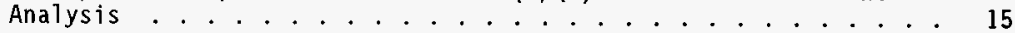

9. Predicted Radiological Consequences For Organic Fire . . . . . . 17

10. Predicted Concentrations of Phosphorous Pentoxide in Organic Fire Plume ...................... 18

11. Predicted Concentrations for Carbon Monoxide in Organic Fire Plume....................... . . . 19

12. Predicted Radiological Consequences For $\mathrm{H}_{2}$ Explosion And Organic Fire ........................

13. Maximum ${ }^{90} \mathrm{Sr}$ and ${ }^{137} \mathrm{Cs}$ Quantities (Ci) Prior To Placement of Tank Onto Concrete Pad 


\section{LIST OF TERMS}

$\begin{array}{ll}\text { ALARA } & \text { as low as reasonably achievable } \\ \text { ARF } & \text { airborne release fraction } \\ \text { ARR } & \text { airborne release rate } \\ \text { Bq } & \text { Becquerel } \\ \text { BR } & \text { breathing rate } \\ \text { Ci } & \text { curie } \\ \text { D2EHPA } & \text { Di-2-ethylhexyl phosphoric acid } \\ \text { DCF } & \text { dose conversion factor } \\ \text { DOE-RL } & \text { U.S. Department of Energy-Richland Field office } \\ \text { EDE } & \text { effective dose equivalent } \\ \text { ERPG } & \text { emergency response planning guideline } \\ \text { HAZOP } & \text { Hazard and Operability } \\ \text { HEPA } & \text { high efficiency particulate air (filter) } \\ \text { ICRP } & \text { International Commission on Radiological Protection } \\ \text { ISB } & \text { interim safety basis } \\ \text { LSA } & \text { low specific activity } \\ \text { LLW } & \text { low level waste } \\ \text { MeV } & \text { million electron volt } \\ \text { NIOSH } & \text { National Institute for Occupational Safety and Health } \\ \text { NPH } & \text { normal paraffin hydrocarbon } \\ \text { PHA } & \text { preliminary hazards analysis } \\ \text { mPa } & \text { mega-pascal } \\ \text { MR } & \text { mass ratio } \\ \text { PEL-TWA } & \text { permissible exposure limit - time weighted average } \\ \text { PSi } & \text { pounds per square inch } \\ \text { RCT } & \text { Radiological Control Technician } \\ \text { S\&M } & \text { Surveillance and Maintenance } \\ \text { SSC } & \text { structure, system, and component } \\ \text { SV } & \text { Sievert } \\ \text { TBP } & \text { tributyl phosphate } \\ \text { USQ } & \text { unreviewed safety question } \\ \text { WESF } & \text { Waste Encapsulation and Storage Facility } \\ \text { WHC } & \text { Westinghouse Hanford Company } \\ \text { X/Q } & \text { atmospheric dispersion factor } \\ & \end{array}$


HNF-SD-OPS-SAD-001, Rev. 0

This page intentionally left blank. 


\section{HNF-SD-OPS-SAD-001, Rev. 0 \\ SAFETY ASSESSMENT FOR STORAGE OF ORGANIC LIQUIDS AT B PLANT}

\subsection{SCOPE}

The $B \mathrm{Pl}$ ant facility is currently undergoing preparations for transition to surveillance and maintenance (S\&M). Organic liquid waste is to be stored outside of $\mathrm{B} P \mathrm{Plant}$ in a tank located on a concrete pad approximately $100 \mathrm{~m}$ $(328 \mathrm{ft})$ NNE of the NE corner of the plant. An Unreviewed Safety Question (USQ) screening was conducted and it was determined that the liquid storage of radioactive contaminated organic liquids outside the 221-B canyon ventilation area such as the proposed activity was not covered by the existing Safety Bas is of B Plant. This Safety Assessment (SA) supports the USQ Evaluation and addresses the outside storage of the organic liquid waste.

\subsection{DESCRIPTION OF SYSTEM}

The storage tank has a capacity of $17,500 \mathrm{~L}(4,623$ gal). The concrete pad has a $0.6 \mathrm{~m}$ ( $2 \mathrm{ft}$ ) high berm that acts as a secondary containment feature to contain any leaks that might occur during storage. The berm area is approximately $5.1-\mathrm{m}(16.7-\mathrm{ft})$ by $9.14-\mathrm{m}(30.0-\mathrm{ft})$ with a total capacity of 28 $\mathrm{m}^{3}\left(2.8 \times 10^{4} \mathrm{~L}\right)$. The concrete pad will have a fence surrounding it and no electrical connections are provided to the tanks except for grounding connections. There will also be a spare tank identical to the primary tank located on the concrete pad. The spare tank can be used to store the organic liquid in case of any leak or required maintenance on the primary tank. The tanks are designed with passive ventilation systems, being vented through HEPA filters to reduce any potential emissions. The passive vent system has been specifically designed to maintain hydrogen concentrations in the headspace of the tanks at approximately 2 vol\%, below the lower flammable limit (LFL) of hydrogen in air, which is 4 vol\%. The spare tank located on the same concrete pad will have its own secondary containment (berm). Both tanks are rated at $1.7 \mathrm{MPa}$ (250 psi). Any transfer from the primary tank to the spare will use an air driven pump. The Safety Assessment For Removal of Organic Liquids From $B$ Plant (WHC 1996a) analyzed the potential spray release consequences from transfer of the organic liquid into the tank located on the flatbed. The radionuclides were analyzed at their maximum allowable concentrations to produce dose consequences of less than $50 \mathrm{mSv}$ ( 5 rem) onsite. The washing and filtering of the organics prior to transfer will result in concentrations less than the maximum allowable. Therefore, as long as the pump pressure does not exceed $0.70 \mathrm{MPa}$ (100 psi) as assumed in WHC 1996a, the consequences of a spray leak due to organic transfer to the spare tank is bounded by WHC 1996a.

\subsection{IDENTIFICATION OF HAZARDS}

As the first step in the development of the USQ Evaluation, a Preliminary Hazards Analysis (PHA) was performed. The PHA used a multidiscipline team of experts (see Appendix B for 1 ists) to examine the safety implications of removal of organic material from B Plant and storage on the 
new organic storage pad outside of $\mathrm{B} P \mathrm{Plant}$. The experts represented $\mathrm{B}$ Plant operations, engineering (design and process), and safety.

The form used for the PHA is included as Table 1. The first column, labelled "Process Step" defines the process step being analyzed. The second column, labelled "Hazardous Condition" refers to a credible abnormal event combined with an intrinsic hazard (radioactivity, toxic material, etc) which may result in adverse consequences to a facility worker and/or a person at a distance from the facility. A checklist (Table 2) was used to help ensure the completeness of the list of hazardous conditions, although the team could postulate hazardous conditions not included in the checklist. The third column, "cause" lists abnormal events which the team believed may initiate the hazardous condition. The fourth column, "consequences", qualitatively describes the postulated consequences of the hazardous condition. The fifth and sixth columns list the engineered and administrative features expected to be included in the design and/or operating procedures which may prevent or mitigate the consequences of the hazardous condition. The lists of equipment and procedures in these columns can be used to demonstrate defense in depth. The lists can also be used as the basis of safety equipment lists and technical specifications. The column labelled "inventory", is a qualitative description of the hazardous material which could potentially be dispersed in the hazardous condition (e. g., organic solvent, TBP, radionuclides, etc). The consequence and frequency category columns serve to qualitatively rank the postulated accident consequences and frequencies.

The safety consequences are ranked in the following four categories:

SO $=$ No safety consequences or environmental events.

S1 = Facility worker injury or exposure to hazardous materials; reportable release of hazardous materials within or near the pad S2 = Hazardous material exposure to person (co-located worker) at a distance from the pad; significant hazardous material discharge beyond the pad

S3 = Hazardous material exposure to the public; hazardous material discharge offsite

The frequencies of the consequences (hazardous condition and failure of mitigative/preventive features) are ranked in the following four categories:

$$
\begin{array}{llrl}
\text { F0 } & =\text { Beyond Extremely Unlikely } & \left(\mathrm{f}<10^{-6} / \mathrm{yr}\right) \\
\text { F1 } & =\text { Extremely Unlikely } & \left(10^{-6} / \mathrm{yr}<\mathrm{f}<10^{-4} / \mathrm{yr}\right) \\
\text { F2 }=\text { Unlikely } & \left(10^{-4} / \mathrm{yr}<\mathrm{f}<10^{-2}\right. \\
\text { F3 }=\text { Anticipated } & \left(10^{-2} / \mathrm{yr}<\mathrm{f}\right)
\end{array}
$$

The "remarks" column is used to document comments or recommendations that the team felt should be communicated to the operations and design functions.

The information in the PHA table was used to select accidents for detailed analysis for this Safety Assessment, to help develop the accident scenarios, and to assist in the selection of safety-class and safetysignificant structures, systems and components (SSCs). 


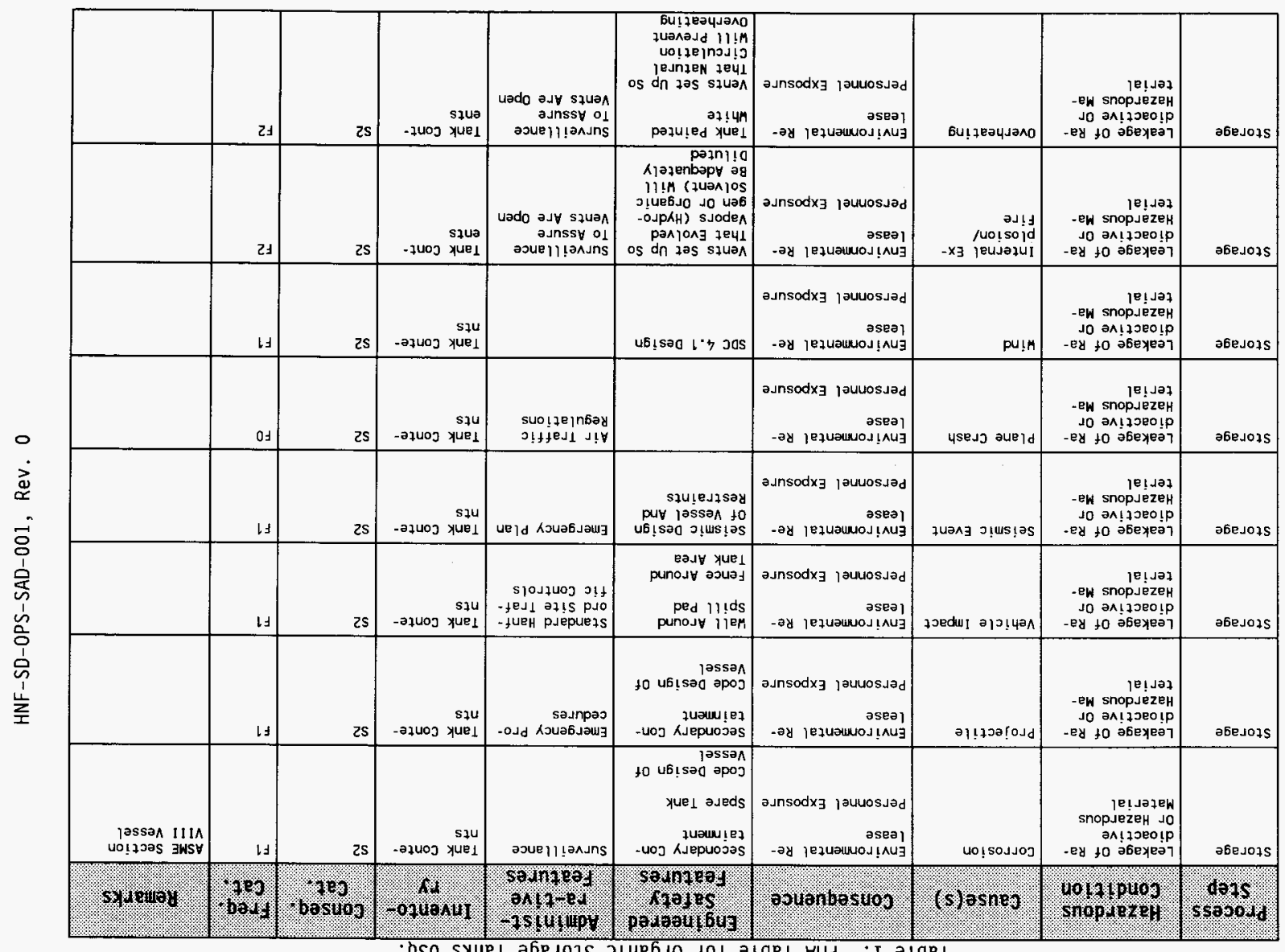

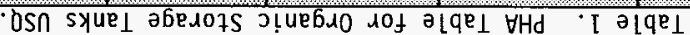


Date: $7 / 18 / 96$

Participants: See List $A$

Table 1. PHA Table for Organic Storage Tanks USQ.

\begin{tabular}{|c|c|c|c|c|c|c|c|c|c|}
\hline Process & $\begin{array}{l}\text { Hazardous } \\
\text { condit tion. }\end{array}$ & causers) & consequence & $\begin{array}{l}\text { Enguneered } \\
\text { Saretry } \\
\text { fentures. }\end{array}$ & 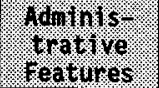 & mivento & gonseq & (6ot). & Reiands \\
\hline Storage & $\begin{array}{l}\text { Direct Radia- } \\
\text { tion Dose }\end{array}$ & $\begin{array}{l}\text { Proximity To } \\
\text { Tank }\end{array}$ & $\begin{array}{l}\text { Dose To Facility } \\
\text { Worker Exceeding } \\
\text { Hanford Standards } \\
\end{array}$ & Locked Fence & $\begin{array}{l}\text { Posted As A } \\
\text { High Radiation } \\
\text { Area }\end{array}$ & N/A & sit & F2 & \\
\hline Storage & $\begin{array}{l}\text { Ventilation } \\
\text { System HEPA } \\
\text { Fitter or Vent } \\
\text { Tube Blockage }\end{array}$ & $\begin{array}{l}\text { Filter freez- } \\
\text { ing }\end{array}$ & $\begin{array}{l}\text { Hydrogen Buildup } \\
\text { (Fire) } \\
\text { Filter Faillure } \\
\text { (Airborne Release) }\end{array}$ & & $\begin{array}{l}\text { Downstream Air } \\
\text { Sample }\end{array}$ & $\begin{array}{l}\text { Tank Conten- } \\
\text { ts (Fire) } \\
\text { Filter In- } \\
\text { ventory; } \\
\text { Tank Atmo- } \\
\text { sphere }\end{array}$ & s2 & F2 & \\
\hline Storage & $\begin{array}{l}\text { Ventilation } \\
\text { System HEPA } \\
\text { Filter Or Vent } \\
\text { Tube Blockage }\end{array}$ & $\begin{array}{l}\text { Animal Intru- } \\
\text { sion }\end{array}$ & $\begin{array}{l}\text { Hydrogen Buildup } \\
\text { (Fire) } \\
\text { Filter Failure } \\
\text { (Airborne Release) }\end{array}$ & $\begin{array}{l}\text { Design Provi- } \\
\text { sions }\end{array}$ & & $\begin{array}{l}\text { Tank Conten- } \\
\text { ts (Fire) } \\
\text { Filter In- } \\
\text { ventory; } \\
\text { Tank Armo- } \\
\text { sphere }\end{array}$ & s2 & $\mathrm{F2}$ & \\
\hline Storage & $\begin{array}{l}\text { Ventilation } \\
\text { System HEPA } \\
\text { Fitter or Vent } \\
\text { Tube Blockage }\end{array}$ & Snow & $\begin{array}{l}\text { Hydrogen Buildup } \\
\text { (Fire) } \\
\text { Filter Failure } \\
\text { (Airborne Release) }\end{array}$ & & & $\begin{array}{l}\text { Tank Conten- } \\
\text { ts (Fire) } \\
\text { Filter In- } \\
\text { ventory } \\
\text { Tank Atmo- } \\
\text { sphere }\end{array}$ & s2 & $F 2$ & \\
\hline Storage & $\begin{array}{l}\text { Ventilation } \\
\text { System HEPA } \\
\text { Fitter or Vent } \\
\text { Tube Blockage }\end{array}$ & $\begin{array}{l}\text { Organic Build- } \\
\text { up }\end{array}$ & $\begin{array}{l}\text { Hydrogen Buildup } \\
\text { (Fire) } \\
\text { Filter Failure } \\
\text { (Airborne Release) }\end{array}$ & & $\begin{array}{l}\text { Periodic Fil- } \\
\text { ter Replace- } \\
\text { ment }\end{array}$ & $\begin{array}{l}\text { Tank Conten- } \\
\text { ts (Fire) } \\
\text { Filter In- } \\
\text { ventory } \\
\text { Tank Atmo- } \\
\text { sphere }\end{array}$ & s2 & $F 1$ & \\
\hline Storage & $\begin{array}{l}\text { Ventilation } \\
\text { System HEPA } \\
\text { Filter or Vent } \\
\text { Tube Blockage }\end{array}$ & $\begin{array}{l}\text { Waste Blocking } \\
\text { Tube }\end{array}$ & $\begin{array}{l}\text { Hydrogen Buildup } \\
\text { (Fire) } \\
\text { Filter Failure } \\
\text { (Airborne Release) }\end{array}$ & & $\begin{array}{l}\text { Maintaining } \\
\text { Adequate Free- } \\
\text { board }\end{array}$ & $\begin{array}{l}\text { Tank Conten- } \\
\text { ts (Fire) } \\
\text { Filter In- } \\
\text { ventory } \\
\text { Tank Atmo- } \\
\text { sphere }\end{array}$ & $\begin{array}{l}\text { Controlled } \\
\text { By } \\
\text { Degree of } \\
\text { Cleanup }\end{array}$ & F2 & \\
\hline
\end{tabular}


Date: $7 / 18 / 96$

Participants: See List $A$

Table 1. PHA Table for Organic Storage Tanks USQ.

\begin{tabular}{|c|c|c|c|c|c|c|c|c|c|}
\hline Process & 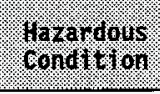 & manses & oromequence & 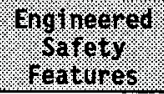 & 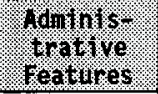 & monto & morar & 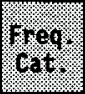 & henars \\
\hline Storage & $\begin{array}{l}\text { Vent ilation } \\
\text { System HEPA } \\
\text { Filter Or Vent } \\
\text { Tube Blockage }\end{array}$ & $\begin{array}{l}\text { Failure To } \\
\text { Open Vent } \\
\text { Valve After } \\
\text { Tank Transfer }\end{array}$ & $\begin{array}{l}\text { Hydrogen Buildup } \\
\text { (Fire) } \\
\text { Tank Rupture }\end{array}$ & & $\begin{array}{l}\text { Inspection of } \\
\text { rank to Ensure } \\
\text { valve is Open }\end{array}$ & $\begin{array}{l}\text { Tank Conten- } \\
\text { ts (Fire) } \\
\text { Filter In- } \\
\text { ventory } \\
\text { Tank Atmo- } \\
\text { sphere }\end{array}$ & s2 & $F 2$ & \\
\hline Storage & Fire & Range Fire & $\begin{array}{l}\text { Airborne Radioac- } \\
\text { tive Release } \\
\text { Expansion } \\
\text { Airborne Toxic } \\
\text { Release }\end{array}$ & $\begin{array}{l}\text { Fence And Grav- } \\
\text { el Surrounding } \\
\text { The Tank Spill } \\
\text { Pad }\end{array}$ & Housekeeping & $\begin{array}{l}\text { Tank Con- } \\
\text { tents (Fire) } \\
\text { Filter In- } \\
\text { ventory } \\
\text { Tank Atmosp- } \\
\text { here }\end{array}$ & $\$ 2$ & $F 2$ & \\
\hline Storage & Fire & $\begin{array}{l}\text { Vehicle Acci- } \\
\text { dent }\end{array}$ & $\begin{array}{l}\text { Airborne Radioac- } \\
\text { tive Release } \\
\text { Expansion } \\
\text { Airborne Toxic } \\
\text { Release }\end{array}$ & $\begin{array}{l}\text { Fence Surround- } \\
\text { ing The Iank } \\
\text { And Spill Pad }\end{array}$ & $\begin{array}{l}\text { Standard } \\
\text { Hanford Traf- } \\
\text { fic Controls }\end{array}$ & $\begin{array}{l}\text { Tank Con- } \\
\text { tents (Fire) } \\
\text { Filter In- } \\
\text { ventory } \\
\text { Jank Atmosp- } \\
\text { here }\end{array}$ & s2 & F1 & \\
\hline Storage & Fire & Lightning & $\begin{array}{l}\text { Airborne Radioac- } \\
\text { tive Release } \\
\text { Expansion } \\
\text { Airborne Toxic } \\
\text { Release }\end{array}$ & $\begin{array}{l}\text { Grounding of } \\
\text { Tank }\end{array}$ & $\begin{array}{l}\text { oc Inspection } \\
\text { And Periodic } \\
\text { Maintenance of } \\
\text { Grounding }\end{array}$ & $\begin{array}{l}\text { Tank Con- } \\
\text { tents (Fire) } \\
\text { Filter In- } \\
\text { ventory } \\
\text { Tank Atmosp- } \\
\text { here }\end{array}$ & s2 & F1 & \\
\hline Storage & Fire & welding & $\begin{array}{l}\text { Airborne Radioac- } \\
\text { tive Release } \\
\text { Expansion } \\
\text { Airborne Toxic } \\
\text { Release }\end{array}$ & & $\begin{array}{l}\text { Standard Con- } \\
\text { trols On Weld- } \\
\text { ing Activity }\end{array}$ & $\begin{array}{l}\text { Tank Con- } \\
\text { tents (Fire) } \\
\text { Filter In- } \\
\text { ventory } \\
\text { Tank Atmosp- } \\
\text { here }\end{array}$ & s2 & $F 2$ & \\
\hline storage & Fire & Ma intenance & $\begin{array}{l}\text { Airborne Radioac- } \\
\text { tive Release } \\
\text { Airborne Toxic } \\
\text { Release }\end{array}$ & & $\begin{array}{l}\text { Administrat ive } \\
\text { Controls On } \\
\text { Maintenance } \\
\text { Activity }\end{array}$ & $\begin{array}{l}\text { Tank Con- } \\
\text { tents (Fire) } \\
\text { Filter In- } \\
\text { ventory } \\
\text { Tank Atmosp- } \\
\text { here }\end{array}$ & s2 & F2 & \\
\hline
\end{tabular}




\begin{tabular}{|c|c|c|c|c|c|c|c|c|c|}
\hline & & & & & $\begin{array}{r}\text { SO!JUUOSS } \\
\text { aj!f əOS }\end{array}$ & دנ! sy aues & $\begin{array}{l}\text { (as!y } 20 S) \\
\text { sasnej JaY40 }\end{array}$ & $\mathrm{u}$ ! $\mathrm{so} \mathrm{dx} \mathrm{x}$ & 26e-J07S \\
\hline & It & 2s & 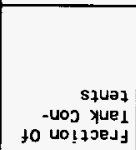 & 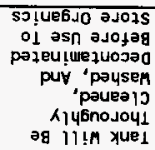 & & a & 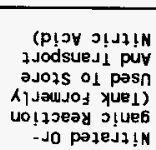 & vol 50 jof & ว6e.J07S \\
\hline & $2 \pm$ & 2s & $\begin{array}{r}\text { s7uez } \\
-405 \text { ॠU81 }\end{array}$ & 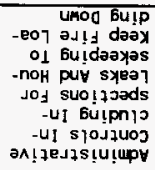 & U6! sad \पe 1 & 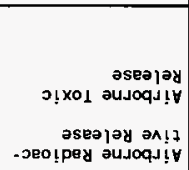 & 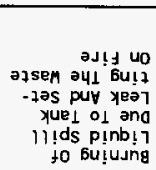 & لـ إلده & 26e 1075 \\
\hline & Lt & IS & 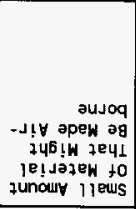 & & 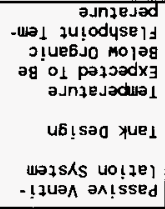 & 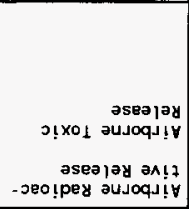 & 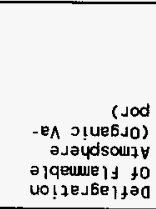 & 1 & a6eJ015 \\
\hline & b & Is & 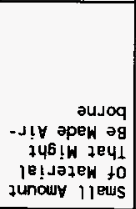 & 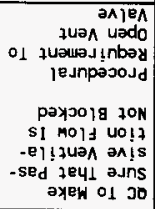 & 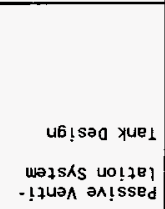 & 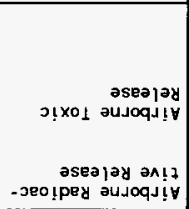 & 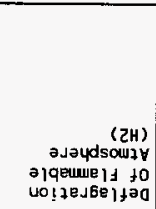 & as! & a6e Jo7s \\
\hline s. & worog & bosuog & .041040 & 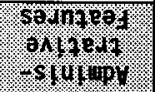 & 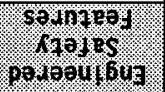 & tosusniosilog & $(s)$ osnes & sionoplezer & thoogory \\
\hline
\end{tabular}

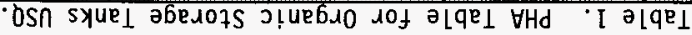


Table 2. PHA Checklist.

\begin{tabular}{|l|}
\hline $\begin{array}{l}\text { External Radioactive } \\
\text { Contamination }\end{array}$ \\
\hline Internal Radiation Dose \\
\hline Criticality \\
\hline Loss of Shielding \\
\hline Loss of Liquid Containment \\
\hline Ventilation \\
\hline Fire \\
\hline Explosion \\
\hline Maintenance Problem \\
\hline Impact \\
\hline Loss of Utilities \\
\hline Corrosion/Erosion \\
\hline Extreme Weather \\
\hline Seismic Event \\
\hline Toxicity \\
\hline Construction Hazard \\
\hline
\end{tabular}

\subsection{HAZARDS ANALYSIS}

\subsection{BASIC APPROACH}

The basic approach is to focus on the accidents that potentially produce the maximum consequences. Using the graded approach, little resources are spent initially on determining the frequency of the accidents, but rather they are assumed to be credible and the consequences are determined. If the consequences, even at a probability of one are acceptable, no further analysis is provided.

A review of the PHA table revealed that the most serious credible hazards with the potentially highest consequences were: a) a fire, b) a hydrogen explosion caused by an ignition source and the hydrogen exceeding 4 vol\% in the headspace, and c) a spill of the liquid organic. B plant personnel are planning to reduce the quantities of the ${ }^{137} \mathrm{Cs}$ and ${ }^{90} \mathrm{Sr}$ in the organic liquid as much as possible prior to transferring the liquid outside of the $B$ Plant canyon area. The goal is to reduce the values of the radionuclides such that the liquid can be declared as Low Specific Activity (LSA).

To assist in determining to what minimum level the two radionuclides $\left({ }^{137} \mathrm{Cs}\right.$ and ${ }^{90} \mathrm{Sr}$ ) must be reduced, the concentrations were back-calculated (see Appendix A) to determine the allowable concentrations for an unmitigated (no berm) and mitigated (with berm) burning scenarios without exceeding the WHC onsite and offsite guidelines. These guidelines, from WHC-CM-4-46 (WHC 1996b), are summarized in Table 3 . The $50 \mathrm{mSv}$ ( 5 rem) onsite criterion was chosen for the goal of the project. This approach is conservative as plume 


\begin{tabular}{|c|c|c|c|c|c|}
\hline & & $S L^{\circ} b$ & $\varepsilon L^{\circ} I \varepsilon Z$ & $9 Z^{\prime} Z$ & $\bar{s} I^{\circ} Z \varepsilon 己$ \\
\hline $00^{\circ} L$ & $\mathcal{G} \varepsilon^{\circ} I \varepsilon Z$ & $0 S^{\circ} t$ & $\angle L^{\circ} I \varepsilon Z$ & $00^{\circ} 2$ & $6 I \cdot Z \varepsilon Z$ \\
\hline$S L 99$ & $6 \varepsilon^{\circ}$ IEZ & $92 \cdot 6$ & $โ 8^{\circ} โ \varepsilon 己$ & $S L^{\circ} I$ & $\varepsilon Z \cdot 2 \varepsilon Z$ \\
\hline $0 \mathcal{S}^{\circ} 9$ & $\varepsilon b^{\circ} I \varepsilon Z$ & $00^{\circ} 6$ & $98^{\circ}$ I & $0 S^{\circ} \mathrm{I}$ & $\angle Z \cdot Z \varepsilon Z$ \\
\hline $92 \cdot 9$ & $\angle b^{\circ} I \varepsilon Z$ & $G L^{\prime} \varepsilon$ & $68^{\circ}$ I $\varepsilon 2$ & $G Z^{*} \mathrm{I}$ & $Z \varepsilon^{\cdot} Z \varepsilon Z$ \\
\hline $00 \% 9$ & $29^{\circ} I \varepsilon Z$ & $09^{\circ} \varepsilon$ & $76^{\circ} I \varepsilon 2$ & $00^{\circ} \mathrm{I}$ & $9 \varepsilon \cdot 2 \varepsilon z$ \\
\hline $\mathrm{SL} \mathrm{G}$ & $99^{\circ}$ I $\varepsilon Z$ & $\mathrm{sZ} \varepsilon$ & $86^{\circ} I \varepsilon Z$ & $9 L^{\circ} 0$ & $0 t^{\circ} 2 \varepsilon Z$ \\
\hline $0 \mathcal{G}^{\circ} \mathrm{S}$ & $09^{\circ} \mathrm{I \varepsilon Z}$ & $00^{\circ} \varepsilon$ & $20^{\circ} 2 \varepsilon 2$ & $09^{\circ} 0$ & $6 t^{\circ} 2 \varepsilon z$ \\
\hline $92^{\circ} \mathrm{S}$ & $69^{\circ} I \varepsilon Z$ & $\mathrm{SL} Z \mathrm{Z}$ & $90^{\circ} 2 \varepsilon 2$ & $92^{\circ} 0$ & $86^{\circ} 2 \varepsilon Z$ \\
\hline $00^{\circ} \mathrm{S}$ & $89^{*}[\varepsilon Z$ & $0 S^{\circ} 2$ & {$\left[I^{\bullet} Z \varepsilon Z\right.$} & 0 & $\varepsilon G^{\cdot} Z \varepsilon Z$ \\
\hline$(101) S_{3}$ & $1485_{6}$ & $60 \%$ y & 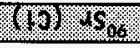 & $(19)$ & $(6) 1_{66}$ \\
\hline
\end{tabular}

\begin{tabular}{|c|c|c|c|c|}
\hline (sz) $09 z$ & $(00 I) 000 L$ & $z-9 d d \exists$ & $\varepsilon-9 d d]$ & OI $>07,0$. $07<$ \\
\hline (s) $0 \mathrm{~S}$ & (sz) $09 z$ & [-9dy] & $2-9 d 83$ & $z-0 I 507,0$, $<$ \\
\hline$\left(\mathrm{s}^{\circ} 0\right) \mathrm{s}$ & (s) $0 \mathrm{~s}$ & $\forall M \perp-7 \exists d$ & [-9dע $]$ & ${ }_{0} 0 I>072.0 I<$ \\
\hline $27 ! 5+10$ & әq!su0 & ә7!s+10 & 27!suo & \multirow{2}{*}{ 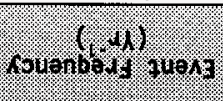 } \\
\hline 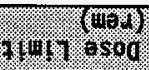 & 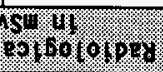 & $400 \%+44650 \%$ & Hor & \\
\hline
\end{tabular}

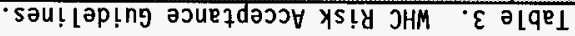

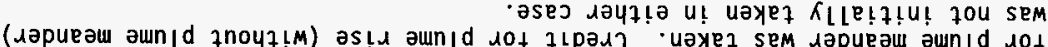

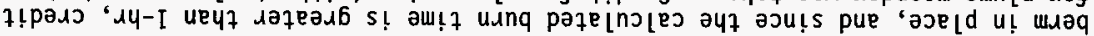

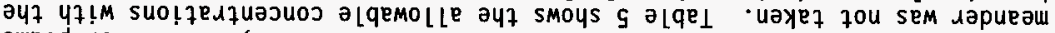

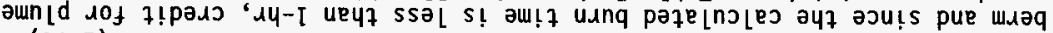

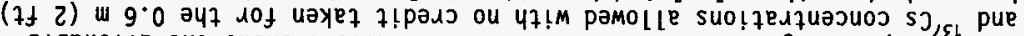
${ }^{1 S_{06}}$ ә

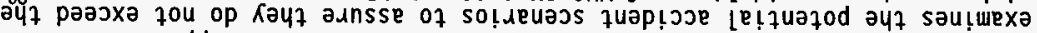

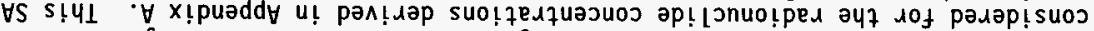

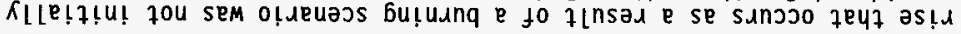


Table 5. Maximum ${ }^{90} \mathrm{Sr}$ and ${ }^{137} \mathrm{Cs}$ Quantities (Ci) Prior To Placement of Tank Onto Concrete Pad (Berm In Place).

\begin{tabular}{|c|c|c|c|c|c|}
\hline sor 10 & 970 o o & So $14 \%$ & $187.8 .601)$ & s. S - (c) & 305,01 \\
\hline 707.87 & 0 & 707.45 & 2.50 & $707 . .03$ & 5.00 \\
\hline 707.83 & 0.25 & 707.40 & 2.75 & 706.98 & 5.25 \\
\hline 707.78 & 0.50 & 707.36 & 3.00 & 706.94 & 5.50 \\
\hline 707.74 & 0.75 & 707.32 & 3.25 & 706.90 & 5.75 \\
\hline 707.70 & 1.00 & 707.28 & 3.50 & 706.86 & 6.00 \\
\hline 707.66 & 1.25 & 707.24 & 3.75 & 706.81 & 6.25 \\
\hline 707.61 & 1.50 & 707.19 & 4.00 & 706.77 & 6.50 \\
\hline 707.57 & 1.75 & 707.15 & 4.25 & 706.73 & 6.75 \\
\hline 707.53 & 2.00 & 707.11 & 4.50 & 706.69 & 7.00 \\
\hline 707.49 & 2.25 & 707.07 & 4.75 & & \\
\hline
\end{tabular}

\subsection{LIQUID SPILL AND BURNING SCENARIO}

One possible scenario involves an accident in which the tank is breached and the organic liquid is spilled and an ignition source is present, causing a radioactive release from the burning organic. Two burning scenarios are possible. One in which the liquid is contained within the berm surrounding the tank, while a second is one in which the berm is breached and the resultant burn area is increased. B Plant Interim Safety Basis Accident Analysis (WHC 1996c) analyzed a spill and burning of the organic liquid within $B$ Plant. The same methodology is used in this SA to calculate the burn time as well as determining the airborne release fractions (ARFs) that release radioactive material in the respirable range. The accident scenario analyzed in the B Plant ISB and adopted for this SA include the following assumptions:

- The composition of the organic material in the tank is $70 \% \mathrm{NPH}$, $10 \%$ TBP, and $20 \%$ D2EHPA. The specific gravity of this material is 0.82 . The organic is modeled by using the properties of kerosene.

- The length of exposure for either the onsite or offsite individual to the fire is limited to 8 hours and 24 hours.

- The cesium and strontium in the burning organic are converted to particulate oxides. Cesium is semivolatile with an airborne release fraction (ARF) of $1 \%$. According to the Nuclear Fuel Cycle Facility Accident Analysis Handbook, NUREG 1320, strontium is nonvolatile with an ARF of $0.77 \%$ (Ayer et a1. 1988).

The surface area for a spill with the berm intact is $46.6 \mathrm{~m}^{2}$ and with $15,140 \mathrm{~L}(4,000 \mathrm{gal})$ of organic liquid, the depth of the spilled organic from the tank is $0.32 \mathrm{~m}$ ( $1 \mathrm{ft}$ ). The fuel burn rate is equal to the mass loss rate of fuel, $M_{b}$. This is calculated by the following equations (Ayer et al. 1988). The values for the heat fluxes, the heat of vaporization, and radiative heat loss in the following equation are obtained from Ayer et al. (1988). 


$$
\begin{aligned}
\dot{\mathrm{M}}_{\mathrm{b}} & =\frac{\left(\dot{q}_{e}^{\prime \prime}+\dot{\mathrm{q}}_{\mathrm{fc}}^{\prime \prime}+\dot{\mathrm{q}}_{\mathrm{fr}}^{\prime \prime}-\dot{\mathrm{q}}_{\mathrm{rr}}^{\prime \prime}\right) \text { area }}{\mathrm{L}} \\
& =\frac{\left(0 \frac{\mathrm{kW}}{\mathrm{m}^{2}}+11 \frac{\mathrm{kW}}{\mathrm{m}^{2}}+14 \frac{\mathrm{kW}}{\mathrm{m}}-8 \frac{\mathrm{kw}}{\mathrm{m}^{2}}\right)\left(46.6 \mathrm{~m}^{2}\right)}{1.5 \frac{\mathrm{kJ}}{\mathrm{g}}\left(\frac{\mathrm{w}-\mathrm{s}}{\mathrm{J}}\right)} \\
& =528 \frac{\mathrm{g}}{\mathrm{s} .}
\end{aligned}
$$

where

$\dot{q}_{e}^{\prime \prime}=$ external heat flux per unit surface area, $\frac{\mathrm{kW}}{\mathrm{m}^{2}}$

$\dot{q}_{\mathrm{fc}}^{\prime \prime}=f l$ ame convective heat flux, $\frac{\mathrm{kW}}{\mathrm{m}^{2}}$

$\dot{\mathrm{q}}_{\mathrm{fr}}^{\prime \prime}=$ flame radiative heat flux, $\frac{\mathrm{kW}}{\mathrm{m}^{2}}$

$\dot{\mathbf{q}}_{\mathrm{rr}}^{\prime \prime}=$ surface radiative heat loss, $\frac{\mathrm{kW}}{\mathrm{m}^{2}}$

$A=$ burning surface of fuel, $\mathrm{m}^{2}$

$L=$ heat required to generate a unit mass of fue $]$ vapors, (i.e., the latent heat of vaporization) $\frac{\mathrm{kJ}}{\mathrm{g}}$.

The duration of the burn, which is assumed not extinguished, is found by:

$$
\text { burn time }=\frac{\text { volume } x \text { density }}{\text { burn rate }}=\frac{15,140 \mathrm{~L}\left(820 \frac{\mathrm{g}}{\mathrm{L}}\right)}{\left(528 \frac{\mathrm{g}}{\mathrm{sec}}\right)\left(3,600 \frac{\mathrm{sec}}{\mathrm{hour}}\right)}=6.5 \text { hour. }
$$

Without the berm, the spill area is considerably larger. To estimate the spill area without a berm, the values cited in $A$ Simple Formula for Estimating Source Strengths From Spills of Toxic Liquids (Clewell 1983) is used. Clewell cites the value of a spill onto concrete or non-porous surfaces as being approximately $1.2 \mathrm{~m}^{2} / \mathrm{L}$ of spilled liquid. For spills onto gravel or other porous surfaces, a value of $0.15 \mathrm{~m}^{2} / \mathrm{L}$ is cited. The value of $0.15 \mathrm{~m}^{2} / \mathrm{L}$ is used, as this is more representative of the spill surface area beyond the pad area. The exact quantity of organic liquid to be stored in the external tank is not known, but could range from $9,460 \mathrm{~L}(2,500 \mathrm{gal})$ up to $15,140 \mathrm{~L}$ $(4,000 \mathrm{gal})$.

With the conservative $15,140 \mathrm{~L}(4,000$ gal) of spilled organic liquid, the spill area becomes approximately $2,270 \mathrm{~m}^{2}$. With a spill area of $2,270 \mathrm{~m}^{2}$, the depth of the organic is initially approximately $0.67 \mathrm{~cm}(1 / 4 \mathrm{in}$.) and the organic liquid will rapidly soak into the soil. Using the same equation above, the estimated burn time without the berm and $15,140 \mathrm{~L}(4,000 \mathrm{gal})$ of organic becomes:

With the less conservative $9,460 \mathrm{~L}(2,500 \mathrm{ga} 7)$ of spilled organic liquid, the spill area becomes approximately $1,420 \mathrm{~m}^{2}$. Using the same 
HNF-SD-OPS-SAD-001, Rev. 0

$$
\begin{aligned}
\dot{\mathrm{M}}_{\mathrm{b}} & =\frac{\left(\dot{q}_{\mathrm{e}}^{\prime \prime}+\dot{q}_{\mathrm{fc}}^{\prime \prime}+\dot{\mathrm{q}}_{\mathrm{fr}}^{\prime \prime}-\dot{q}_{\mathrm{rr}}^{\prime \prime}\right) \text { area }}{\mathrm{L}} \\
& =\frac{\left[0 \frac{\mathrm{kW}}{\mathrm{m}^{2}}+11 \frac{\mathrm{kH}}{\mathrm{m}^{2}}+14 \frac{\mathrm{kH}}{2}-8 \frac{\mathrm{kW}}{\mathrm{m}^{2}}\right]\left(2270 \mathrm{~m}^{2}\right)}{1.5 \frac{\mathrm{kJ}}{\mathrm{g}}\left(\frac{1 \mathrm{w}-\mathrm{s}}{\mathrm{J}}\right)} \\
& =25,700 \frac{\mathrm{g}}{\mathrm{s} .}
\end{aligned}
$$

$$
\text { burn time }=\frac{\text { volume } x \text { density }}{\text { burn rate }}=\frac{15,140 \mathrm{~L}\left(820 \frac{\mathrm{g}}{\mathrm{L}}\right)}{\left(25,700 \frac{\mathrm{g}}{\mathrm{sec}}\right)\left(3,600 \frac{\mathrm{sec}}{\mathrm{hour}}\right)}=.13 \mathrm{hr} .
$$

equation above, the estimated burn time without the berm and 9,460 $\mathrm{L}$

$(2,500 \mathrm{gal})$ of organic becomes:

$$
\begin{aligned}
\dot{\mathrm{M}}_{b} & =\frac{\left(\dot{\mathrm{q}}_{\mathrm{e}}^{\prime \prime}+\dot{\mathrm{q}}_{\mathrm{fc}}^{\prime \prime}+\dot{\mathrm{q}}_{\mathrm{fr}}^{\prime \prime}-\dot{\mathrm{q}}_{\mathrm{rr}}^{\prime \prime}\right) \text { area }}{\frac{\mathrm{L}}{\mathrm{m}^{2}}} \\
& =\frac{\left.\int \frac{\mathrm{kW}}{\mathrm{m}^{2}}+11 \frac{\mathrm{kw}}{\mathrm{m}^{2}}+14 \frac{\mathrm{kW}}{\mathrm{m}^{2}}-8 \frac{\mathrm{kw}}{\mathrm{m}^{2}}\right)\left(1420 \mathrm{~m}^{2}\right)}{1.5 \frac{\mathrm{kJ}}{\mathrm{g}}\left(\frac{1 \mathrm{w}-\mathrm{s}}{\mathrm{J}}\right)} \\
& =16,100 \mathrm{~g}
\end{aligned}
$$

$$
\text { burn time }=\frac{\text { volume } x \text { density }}{\text { burn rate }}=\frac{9,460 \mathrm{~L}\left(820 \frac{\mathrm{g}}{\mathrm{L}}\right)}{\left(16,100 \frac{\mathrm{g}}{\mathrm{sec}}\right)\left(3,600 \frac{\mathrm{sec}}{\mathrm{hour}}\right)}=.13 \mathrm{hr}
$$

As can be seen, the burn times for the unmitigated spills involving either $15,140 \mathrm{~L}(4,000 \mathrm{gal})$ or $9,460 \mathrm{~L}(2,500 \mathrm{gal})$ are the same $(\sim 8 \mathrm{~min})$.

\subsection{HYDROGEN GENERATION WITHIN THE TANK}

As the actual quantity of organic liquid finally transferred to the external tank is not exactly known, various quantities of organic liquid are assumed in order to estimate the hydrogen generation values. A minimum value of $9,460 \mathrm{~L}(2,500 \mathrm{gal}) \mathrm{liquid}$ organic is initially assumed (which allows a maximum headspace), and step-increases are then used to determine the time to generate 4 and 10 vol\% of hydrogen in the headspace of the tank. No credit for the specially designed vent system is taken.

Hydrogen is generated via the radiolysis of water and hydrocarbons. Table 6 provides values for the determination of hydrogen generation rates for ${ }^{137} \mathrm{Cs}$ and ${ }^{90} \mathrm{Sr}$. 
$\mathrm{H}_{2}$ Generation Rate $=(\mathrm{C} i)(\mathrm{E})\left[\mathrm{G}\left(\mathrm{H}_{2}\right)\right] / \mathrm{A}$

Where:

$$
\begin{aligned}
& \text { A = Avagadro's number, molecules/mole } \\
& \mathrm{C} i=\text { Curies in the Liquid } \\
& \mathrm{E}=\text { Total energy of the disintegrations, } \mathrm{eV} / \mathrm{s}-\mathrm{C} i \\
& \mathrm{G}\left(\mathrm{H}_{2}\right)=\text { Molecules } \mathrm{H}_{2} / 100 \mathrm{eV}
\end{aligned}
$$

\begin{tabular}{|c|c|c|}
\hline \multicolumn{2}{|r|}{ 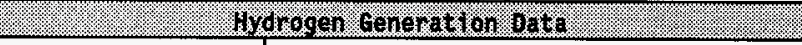 } & Hersenelace \\
\hline $\mathrm{G}\left(\mathrm{H}_{2}\right) /$ Water & 0.45 molecules $/ 100$ electron volt & $\begin{array}{l}\text { RHO-WM-EV-9, } \\
\text { REV IP (RHO 1986) }\end{array}$ \\
\hline $\mathrm{G}\left(\mathrm{H}_{2}\right) /$ Hydrocarbons & 5 molecules/100 electron volt & $\begin{array}{l}\text { RHO-WM-EV-9, } \\
\text { REV IP (RHO 1986) }\end{array}$ \\
\hline $\begin{array}{l}{ }^{137} \mathrm{Cs} \text { (includes } \\
\text { daughters) }\end{array}$ & $3.06 \mathrm{E}+10 \mathrm{MeV} / \mathrm{s} / \mathrm{Ci}$ & $\begin{array}{l}\text { Chart of Nuclides } \\
\text { (GE 1989) }\end{array}$ \\
\hline $\begin{array}{l}{ }^{90} \mathrm{Sr} \text { (includes } \\
\text { daughters) }\end{array}$ & $4.03 \mathrm{E}+10 \mathrm{MeV} / \mathrm{s} / \mathrm{Ci}$ & $\begin{array}{l}\text { Chart of Nuclides } \\
\text { (GE 1989) }\end{array}$ \\
\hline
\end{tabular}$$
\text { Generation Rate }=\text { g-moles } / \mathrm{s}
$$

Table 6. Hydrogen Generation Data.

If there is no ventilation, the steady state value is $100 \%$. The time to reach a value or limit is:

$$
t=-\frac{V}{Q} \ln \left(1-\frac{L F L \&}{V_{s s}}\right)
$$

$V=$ headspace volume

$$
\begin{aligned}
& Q=\text { total gas flow } \\
& V_{s s} \%=\text { steady state volume } \%
\end{aligned}
$$

Where

Since ${ }^{90} \mathrm{Sr}$ has the higher hydrogen generation rate per $\mathrm{C} i$ than ${ }^{137} \mathrm{Cs}$, it is assumed that there are $708 \mathrm{Ci}$ of ${ }^{90} \mathrm{Sr}$ (note that the decay heat is used twice for conservancy). The hydrogen generation for this quantitiy is:

$$
G_{H_{2}}=\frac{708 \mathrm{Ci} * 4.03 \times 10^{16} \mathrm{eV} / \mathrm{s} / \mathrm{Ci} * 5.45 \mathrm{molecules} / 100 \mathrm{eV}}{6.02 \times 10^{23} \mathrm{molecules} / \mathrm{gmole}}=2.6 \times 10^{-6} \mathrm{gmole} / \mathrm{s}
$$

With the assumption that the temperature is $100 \mathrm{~F}$ in the tank vapor space, the volume rate of production is $2.6 \times 10^{-6} \times(560 / 492) \times 22.4=6.63 \times 10^{-5}$ $\mathrm{L} / \mathrm{s}(5.73 \mathrm{~L} /$ day $)$. The tank volume is $17,500 \mathrm{~L}(4,623 \mathrm{gal})$. With $9,460 \mathrm{~L}$ $(2,500 \mathrm{gal})$ of organic liquid in the tank, the headspace volume is $8,040 \mathrm{~L}$ $(2,124 \mathrm{gal})$. The time to steady state for $4 \%$ hydrogen assuming no ventilation is:1 


$$
\begin{array}{r}
\text { HNF-SD-OPS-SAD-001, Rev. } 0 \\
t=-8,040 \frac{L}{5.73 \mathrm{~L} / d} * \ln \left(1-\frac{4}{100}\right)=57 \text { days }
\end{array}
$$

For $10 \%$ hydrogen

$$
t=-8,040 \frac{L}{5.73 L / d} * \ln \left(1-\frac{10}{100}\right)=148 \text { days }
$$

For a headspace volume of $1700 \mathrm{~L}$ (full tank), and $708 \mathrm{Ci}{ }^{90} \mathrm{Sr}$ in the liquid, the time to reach $4 \%$ hydrogen with no ventilation is 12 days.

The headspace (vapor) volume can also be varied and the time to reach a hydrogen concentration value are shown below assuming no ventilation and 708 $\mathrm{Ci}$ of ${ }^{90} \mathrm{Sr}$.

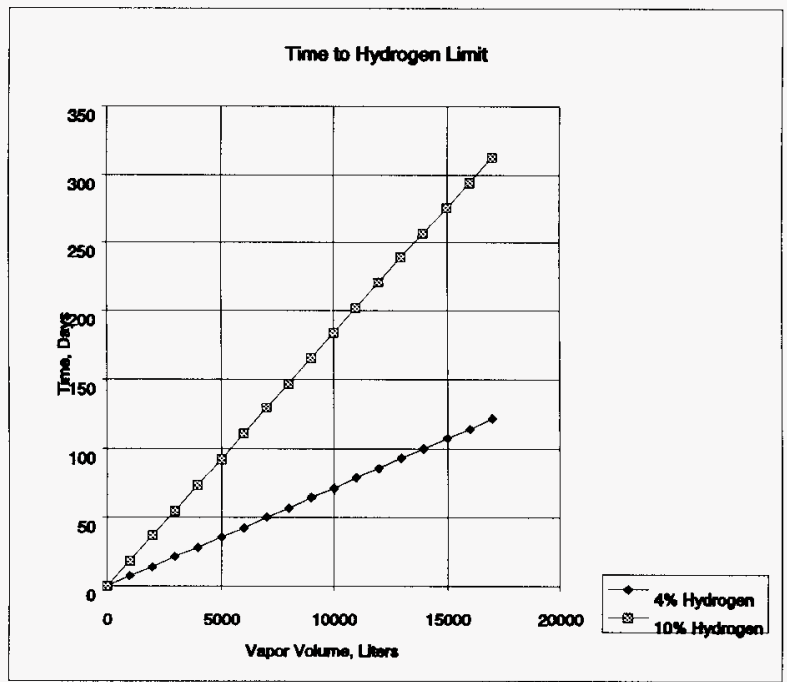

\subsection{CONSEQUENCE OF ACCIDENTS}

\subsection{CONSEQUENCE ANALYSIS METHODOLOGY}

The consequence analysis combines the results of the source term, atmospheric dispersion, and ICRP reference man dose models to estimate consequences to onsite and offsite individuals. For onsite calculations, $100 \mathrm{~m}(328 \mathrm{ft})$ is used as the distance to the onsite receptor. For each of 
sixteen directions, a $99.5 \% X / Q$ (meaning that the $X / Q$ is exceeded only $0.5 \%$ of the time) is calculated along with a $95 \%$ site-wide $X / Q$ (which considers all directions at the same time). The greatest of the seventeen values is selected as the onsite $X / Q$. The onsite $X / Q$ s are from $B$ Plant Interim Safety Basis Accident Analysis (WHC 1996C).

For offsite calculations, the Hanford Site Boundary (i.e., fence line) is used as the location of the offsite receptor. The distances from B Plant to the Hanford Site Boundary are shown in Table 7 . The $95.5 \% X / Q$ values are compared for each of the sixteen directions with the greatest value selected as the offsite $X / Q$. The assumptions and calculations document, supporting Calculations and Assumptions for Use in WESF ISB (Hey 1996) discusses a case where offsite receptor distances correspond to the near side of the Columbia River (as opposed to the current Hanford Site boundary) for that stretch of the river which passes through the Hanford Site. Potential consequences to a receptor at this nearer boundary are also considered for each of the accidents evaluated. The offsite $X / Q \mathrm{~S}$, that were performed for WESF located immediately west of B Plant, are valid for B Plant.

Table 7. Site Boundary Distances Used in Offsite Dispersion Calculations.

\begin{tabular}{|c|c|c|}
\hline 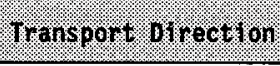 & 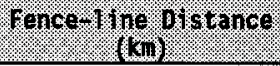 & 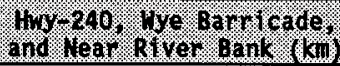 \\
\hline$S$ & 19.31 & 8.94 \\
\hline SSW & 16.64 & 8.26 \\
\hline SW & 18.08 & 8.26 \\
\hline WSW & 19.29 & 9.71 \\
\hline$W$ & 18.89 & 11.04 \\
\hline WNW & 19.39 & 14.36 \\
\hline NW & 19.81 & 11.49 \\
\hline NNW & 19.55 & 11.33 \\
\hline $\mathrm{N}$ & 22.78 & 12.99 \\
\hline NNE & 25.45 & 14.01 \\
\hline NE & 19.88 & 12.27 \\
\hline ENE & 17.04 & 12.14 \\
\hline$E$ & 16.87 & 13.65 \\
\hline ESE & 21.04 & 20.88 \\
\hline SE & 25.17 & 14.19 \\
\hline SSE & 21.08 & 11.71 \\
\hline
\end{tabular}

The radiological doses are determined using the relationship:

$$
\text { Dose }=\mathrm{C} i \times \mathrm{X} / \mathrm{Q} \times \mathrm{BR} \times \mathrm{DCF}
$$

where

$\mathrm{C} \mathrm{C}=$ total curies released as respirable

$X / Q=$ atmospheric dispersion coefficient, $\mathrm{sec} / \mathrm{m}^{3}$

$B R=$ breathing rate, $\mathrm{m}^{3} / \mathrm{sec}\left(3.3 \mathrm{E}-04 \mathrm{~m}^{3} / \mathrm{s}\right)$ 
$\begin{aligned} D C F & =\text { dose conversion factor } \mathrm{rem} / \mathrm{Ci} \\ & =3.19 \mathrm{E}+04 \mathrm{rem} / \mathrm{Ci} \text { for }{ }^{137} \mathrm{Cs} \\ & =2.47 \mathrm{E}+05 \mathrm{rem} / \mathrm{Ci} \text { for }{ }^{90} \mathrm{Sr} \text { (includes the daughter, }{ }^{90} \mathrm{Y} \text { ) }\end{aligned}$

The toxic concentrations are determined using the relationship:

$$
\text { Conc. }\left(\mathrm{mg} / \mathrm{m}^{3}\right)=\text { release rate }(\mathrm{mg} / \mathrm{s}) \times X / Q\left(\mathrm{~s} / \mathrm{m}^{3}\right)
$$

Table 8 shows the onsite and offsite $X / Q$ values which are representative of the dispersion between the $B$ Plant release point and the receptor locations under various release conditions. The particular $X / Q$ value used in an accident analysis is determined based on the physical phenomena associated with the accident. For radiological releases (not involving a burning scenario) lasting 1-hr or longer, credit for plume meander is taken, while for releases less than 1-hr, no credit is taken. For radiological releases from a burning scenario, credit for plume rise is taken. For toxicological releases, credit for plume meander is not taken regardless of release time, but credit for plume rise is taken for burning scenarios. For spills and subsequent burning outside the berm area, two sets of $X / Q$ s are provided. One case is if only $9,460 \mathrm{~L}(2,500 \mathrm{gal})$ is in the tank and spilled, while the other case is if $15,140 \mathrm{~L}(4,000 \mathrm{gal})$ is spilled. For burning scenarios, taking credit for plume rise, onsite receptor locations beyond $100 \mathrm{~m}(328 \mathrm{ft})$ were tested, and the $100 \mathrm{~m}$ (328 ft) location was determined to provide the maximum $X / Q$. The $X / Q$ s taking credit for plume rise are from Atmospheric Dispersion Parameters for B Plant Organic Liquid Storage Fire Scenarios (Himes 1996).

Table 8. Atmospheric Dispersion Coefficients $(X / Q s)$ Used in the Accident Analysis.

\begin{tabular}{|c|c|c|c|}
\hline 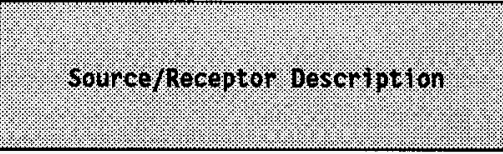 & 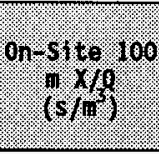 & 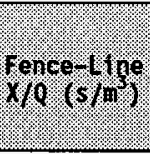 & 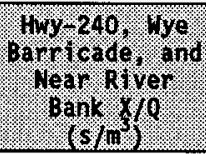 \\
\hline Ground level release, point source & $3.44 \mathrm{E}-02$ & $1.35 \mathrm{E}-0.5$ & $1.90 \mathrm{E}-05$ \\
\hline $\begin{array}{l}\text { Ground level release with plume } \\
\text { meander }\end{array}$ & $1.12 \mathrm{E}-02$ & $1.13 \mathrm{E}-05$ & $1.52 \mathrm{E}-05$ \\
\hline $\begin{array}{l}\text { Burning release with berm and plume } \\
\text { rise }\end{array}$ & $5.49 \mathrm{E}-05$ & $1.54 \mathrm{E}-06$ & $1.67 \mathrm{E}-06$ \\
\hline $\begin{array}{l}\text { Burning release with no berm and } \\
\text { plume rise }(9,460 \mathrm{~L} \text { organic) }\end{array}$ & $4.51 \mathrm{E}-06$ & $1.50 \mathrm{E}-07$ & $2.55 \mathrm{E}-07$ \\
\hline $\begin{array}{l}\text { Burning release with no berm and } \\
\text { plume rise }(15,140 \mathrm{~L} \text { organic) }\end{array}$ & $3.03 \mathrm{E}-06$ & $1.50 \mathrm{E}-07$ & $2.55 \mathrm{E}-07$ \\
\hline
\end{tabular}

\subsection{ORGANIC SPILL AND FIRE (RADIOLOGICAL CONSEQUENCES)}

Tables 4 and 5 provide the results for bounding values for ${ }^{137} \mathrm{Cs}$ and ${ }^{90} \mathrm{Sr}$ combinations, using Mathcad computer software version 5.0. From the

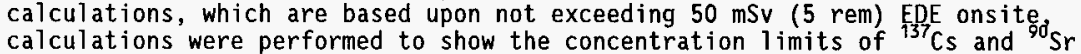
combinations that would not exceed a 5 rem onsite dose from a spill and 
ignition of the organic liquid. The calculations of Table 4 and 5 as derived in Appendix A were used to determine the maximum ${ }^{90} \mathrm{Sr}$ and ${ }^{137} \mathrm{Cs}$ concentrations allowed without credit for plume rise for burning scenarios. However, since plume rise does occur with the burning of the organic liquid, credit may be taken. In the case of no berm in $p l a c e$, since the onsite $X / Q$ is greater for $9,460 \mathrm{~L}(2,500 \mathrm{gal})$ of organic liquid than $15,140 \mathrm{~L}(4,000 \mathrm{gal})$ of total liquid (Table 8 ), it is assumed that $9,460 \mathrm{~L}(2,500 \mathrm{gai})$ is at risk and burns. The higher radionuclide concentrations (Table 5 ) are evaluated, as will be done for all radiological releases, to determine if these higher concentrations may actually be acceptable.

The onsite receptor $X / Q$ at $100 \mathrm{~m}(328 \mathrm{ft})$, in the direction providing the highest $X / Q$ and taking credit for plume rise with the berm in place, is $5.49 \times 10^{-5} \mathrm{~s} / \mathrm{m}^{3}$. Without the berm, the burn area is considerably larger and the onsite $X / Q$ is $4.51 \times 10^{-6} \mathrm{~s} / \mathrm{m}^{3}$. The $X / Q$ for the offsite receptor located at the site boundary (fence-line) with the berm in $\mathrm{place}$ is $1.54 \times 10^{-6} \mathrm{~s} / \mathrm{m}^{3}$, taking credit for plume rise, and $1.50 \times 10^{-7} \mathrm{~s} / \mathrm{m}^{3}$ without the berm. Table 5 provides the higher ${ }^{90} \mathrm{Sr}$ and ${ }^{137} \mathrm{Cs}$ combinations and since all combinations are equivalent from a burning scenario dose consequence, the combination of 707.87 $\mathrm{Ci}$ of ${ }^{90} \mathrm{Sr}$ and $3.0 \mathrm{Ci}$ of ${ }^{937} \mathrm{Cs}$ is arbitrarily chosen to calculate the onsite and offsite consequences. The ARF for the ${ }^{90} \mathrm{Sr}$ is 0.0077 and that for ${ }^{137} \mathrm{Cs}$ is 0.01 . Therefore, $5.45 \mathrm{Ci}$ of ${ }^{90} \mathrm{Sr}$ and $0.03 \mathrm{Ci}$ of ${ }^{137} \mathrm{Cs}$ are released as respirable. For the mitigated case (berm in place), the onsite and offsite doses are calculated using the relationship:

$$
\begin{aligned}
& \text { Dose }=\mathrm{Ci} \times \mathrm{X} / \mathrm{Q} \times \mathrm{BR} \times \mathrm{DCF} \\
& { }^{137} \mathrm{Cs} \text { onsite }=(.03 \mathrm{Ci})\left(5.49 \mathrm{E}-05 \mathrm{~s} / \mathrm{m}^{3}\right)\left(3.3 \mathrm{E}-04 \mathrm{~m}^{3} / \mathrm{s}\right)(3.19 \mathrm{E}+04 \mathrm{rem} / \mathrm{Ci})= \\
& 1.73 \mathrm{E}-04 \mathrm{mSV}(1.73 \mathrm{E}-05 \mathrm{rem}) \\
& { }^{90} \mathrm{Sr} \text { onsite }=(5.45 \mathrm{Ci})\left(5.49 \mathrm{E}-05 \mathrm{~s} / \mathrm{m}^{3}\right)\left(3.3 \mathrm{E}-04 \mathrm{~m}^{3} / \mathrm{s}\right)(2.47 \mathrm{E}+05 \mathrm{rem} / \mathrm{Ci})= \\
& 2.44 \mathrm{E}-01 \mathrm{mSv}(2.44 \mathrm{E}-02 \mathrm{rem}) \\
& { }^{137} \mathrm{Cs} \text { offsite }=(.03 \mathrm{Ci})\left(1.54 \mathrm{E}-06 \mathrm{~s} / \mathrm{m}^{3}\right)\left(3.3 \mathrm{E}-04 \mathrm{~m}^{3} / \mathrm{s}\right)(3.19 \mathrm{E}+04 \mathrm{rem} / \mathrm{Ci})= \\
& 4.86 \text { E-06 mSv (4.86 E-07 rem) } \\
& { }^{90} \mathrm{Sr} \text { offsite }=(5.45 \mathrm{Ci})\left(1.54 \mathrm{E}-06 \mathrm{~s} / \mathrm{m}^{3}\right)\left(3.3 \mathrm{E}-04 \mathrm{~m}^{3} / \mathrm{s}\right)(2.47 \mathrm{E}+05 \mathrm{rem} / \mathrm{Ci})= \\
& 6.84 \mathrm{E}-03 \mathrm{mSv}(6.84 \mathrm{E}-04 \mathrm{rem})
\end{aligned}
$$

In a similar manner, the onsite and offsite consequences are calculated for the unmitigated case (no berm) and the consequences for both cases are summarized in Table 9. As shown in the above calculations, the "mitigated" (with berm) consequences are actually higher than the "unmitigated" (no berm) consequences, which is due to the additional lofting of the plume due to a longer burn time and resultant larger heat generation rate. 
Table 9. Predicted Radiological Consequences For Organic Fire.

\begin{tabular}{|c|c|c|c|}
\hline . & (6) & (6) & 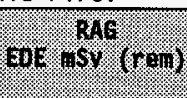 \\
\hline \multicolumn{4}{|c|}{ Unmitigated (No Berm) } \\
\hline Onsite & $4.51 E-06$ & $\begin{array}{l}2.0 \mathrm{E}-02 \\
(2.0 \mathrm{E}-03)\end{array}$ & $50(5)$ \\
\hline Offsite & $1.50 \mathrm{E}-07$ & $\begin{array}{l}6.7 \text { E-04 } \\
(6.7 \text { E-05) } \\
\end{array}$ & $5(0.5)$ \\
\hline \multicolumn{4}{|c|}{ Mitigated (With Berm) } \\
\hline Onsite & $5.49 \mathrm{E}-05$ & $\begin{array}{l}2.4 \mathrm{E}-01 \\
(2.4 \mathrm{E}-02)\end{array}$ & $50(5)$ \\
\hline Offsite & $1.54 \mathrm{E}-06$ & $\begin{array}{l}6.8 \mathrm{E}-03 \\
(6.8 \mathrm{E}-04)\end{array}$ & $5(0.5)$ \\
\hline
\end{tabular}

By comparison, the maximum dose at the alternate site boundary described in Section 5.1, which considers Highway 240 and the near side of the river, is $1.1 \times 10^{-3} \mathrm{mSv}\left(1.1 \times 10^{-4} \mathrm{rem}\right)$ for the unmitigated case, and $7.4 \times 10^{-3} \mathrm{mSv}$ (7.4 E-04 rem) for the mitigated case.

\subsection{ORGANIC SPILL AND FIRE (TOXICOLOGICAL CONSEQUENCES)}

The combustion of organic liquid could produce a smoke plume that contains noxious gases and aerosols. These noxious substances could pose an inhalation hazard to personnel in the path of the plume. In addition to soot particles and gaseous products of incomplete burning of hydrocarbon fuels, the combustion of TBP would produce oxides of phosphorous. The toxicological consequences of solvent fires are evaluated on the basis of predicted concentrations of $\mathrm{P}_{2} \mathrm{O}_{5}$, and $\mathrm{CO}$.

\subsubsection{Phosphorous Pentoxide}

Phosphorous pentoxide is produced by the reaction of TBP and D2EHPA. The TBP and D2EHPA burn are assumed to burn in the following reactions based on incomplete combustion, which results in $15 \%$ of the carbon remaining as carbon monoxide.

$$
\begin{aligned}
& 2\left(\mathrm{C}_{12} \mathrm{H}_{27} \mathrm{PO}_{4}\right)+34 \mathrm{O}_{2} \rightarrow 4 \mathrm{CO}+20 \mathrm{CO}_{2}+27 \mathrm{H}_{2} \mathrm{O}+\mathrm{P}_{2} \mathrm{O}_{5} \cdot \\
& 2 \mathrm{C}_{16} \mathrm{H}_{35} \mathrm{PO}_{4}+46 \mathrm{O}_{2} \rightarrow 4 \mathrm{CO}+28 \mathrm{CO}_{2}+35 \mathrm{H}_{2} \mathrm{O}+\mathrm{P}_{2} \mathrm{O}_{5} .
\end{aligned}
$$

Based on these equations, the $P_{2} 0_{5}$ to TBP mass ratio is 0.27 and 0.22 for D2EHPA. For a burn rate of $528 \mathrm{~g} / \mathrm{sec}$ (with the berm in place) of which $10 \%$ is TBP and $20 \%$ is D2EHPA by mass, the rate of $\mathrm{P}_{2} \mathrm{O}_{5}$ formation is 37.62 g/sec 


$$
\begin{aligned}
\mathrm{P}_{2} \mathrm{O}_{5} \text { mass rate }=528 & \frac{\mathrm{g}}{\mathrm{sec}}[(10 \%)(0.27)+(20 \%)(0.22)] \\
& =37.62 \frac{\mathrm{g}}{\mathrm{sec} .}
\end{aligned}
$$

For a burn rate of $25,700 \mathrm{~g} / \mathrm{sec}$ (without the berm and $15,140 \mathrm{~L}[4,000$ gal] of organic) of which $10 \%$ is TBP and $20 \%$ is D2EHPA by mass, the rate of $\mathrm{P}_{2} \mathrm{O}_{5}$ formation is $1,825 \mathrm{~g} / \mathrm{sec}$

$$
\begin{aligned}
\mathrm{P}_{2} \mathrm{O}_{5} \text { mass rate }=25,700 & \frac{\mathrm{g}}{\mathrm{sec}}[(10 \%)(0.27)+(20 \%)(0.22)] \\
& =1825 \frac{\mathrm{g}}{\mathrm{sec} .}
\end{aligned}
$$

The mitigated (credit for berm and plume rise) onsite and offsite (site boundary) concentrations of $\mathrm{P}_{2} \mathrm{O}_{5}$, calculated using atmospheric dispersion factors for $100 \mathrm{~m}(328 \mathrm{ft})$ and the site boundary, are listed in Table 10 . The ERPG-1, ERPG-2 and ERPG-3 values are $5 \mathrm{mg} / \mathrm{m}^{3}, 25 \mathrm{mg} / \mathrm{m}^{3}$, and $100 \mathrm{mg} / \mathrm{m}^{3}$. The $P E L-T W A$ is $1 \mathrm{mg} / \mathrm{m}^{3}$. The unmitigated onsite concentrations, taking credit for only plume rise, is $5.5 \mathrm{mg} / \mathrm{m}^{3}$ and above the ERPG-1 value of $5 \mathrm{mg} / \mathrm{m}^{3}$. However, this peak concentration lasts for only 8 minutes, the length of the burn, and WHC-CM-4-46 allows the peak 15-min average concentration to be used. The time-weighted average over a 15 -min period becomes $8 / 15 \times 5.5 \mathrm{mg} / \mathrm{m}^{3}=2.9$ $\mathrm{mg} / \mathrm{m}^{3}$. The resulting onsite and offsite concentrations are shown in Table 10

\begin{tabular}{|c|c|c|c|}
\hline gecceptor & (sodgh & Py. pryes cone & $6 \mathrm{at} \cdot \mathrm{ng} / \mathrm{h}$ \\
\hline \multicolumn{4}{|c|}{ Unmitigated (No Berm) } \\
\hline Onsite & $3.03 \mathrm{E}-06$ & 2.9 & 5 \\
\hline Offsite & $1.50 \mathrm{E}-07$ & 0.15 & 1 \\
\hline \multicolumn{4}{|c|}{ Mitigated (With Berm) } \\
\hline Onsite & $5.49 \mathrm{E}-05$ & 2.1 & 5 \\
\hline Offsite & $1.54 \mathrm{E}-06$ & 0.06 & 1 \\
\hline
\end{tabular}
and all are within the guidelines.

Table 10. Predicted Concentrations of Phosphorous Pentoxide in Organic Fire Plume.

RAG $=$ risk acceptance guideline for $>10^{-2}$ to $\leq 10^{\circ}$.

By comparison, the maximum concentration at the alternate site boundary described in Section 5.1, which considers Highway 240 and the near side of the river, is $0.25 \mathrm{mg} / \mathrm{m}^{3}$ for the unmitigated case, and $0.06 \mathrm{mg} / \mathrm{m}^{3}$ for the mitigated case.

Similar calculations as above but using $9,460 \mathrm{~L}(2,500 \mathrm{gal})$ of organic liquid spilled over a $1,420 \mathrm{~m}^{2}$ area results in a $\mathrm{P}_{2} \mathrm{O}_{5}$ release rate of 1,140 $\mathrm{g} / \mathrm{s}$ and the resulting concentrations are slightly less than those shown in Table 10 . 


\subsubsection{Carbon Monoxide}

The mass of $\mathrm{CO}$ formed is estimated on the basis of an emission factor for highly inefficient combustion. For example, the highest emission factor for CO cited in Pollution Control Technology (Fogiel 1973) is $0.0425 \mathrm{~kg}$ for open burning of municipal refuse. Using the previous equations, the calculated CO to TBP mass ratio is 0.21 and 0.174 for D2EHPA. For the organic burn rate of $528 \mathrm{~g} / \mathrm{sec}$ (mitigated, with berm), of which is 10\% TBP and 20\% D2EHPA by mass, the rate of C0 formation is $29.4 \mathrm{~g} / \mathrm{sec}$.

$$
\text { CO mass rate }=528 \frac{\mathrm{g}}{\mathrm{sec}}[(10 z)(0.21)+(20 \%)(0.174)]=29.4 \frac{\mathrm{g}}{\mathrm{sec}} \text {. }
$$

For the organic burn rate of $25,700 \mathrm{~g} / \mathrm{sec}$ (unmitigated, with no berm), of which is $10 \%$ TBP and 20\% D2EHPA by mass, the rate of CO formation is 1,434 g/sec.

CO mass rate $=25,700 \frac{\mathrm{g}}{\mathrm{sec}}[(10 \%)(0.21)+(20 \%)(0.174)]=1434 \frac{\mathrm{g}}{\mathrm{sec}}$.

Unmitigated (no berm) and mitigated (with berm) onsite and offsite concentrations of carbon monoxide, calculated using atmospheric dispersion factors for $100 \mathrm{~m}(328 \mathrm{ft})$ and the site boundary are 1 isted in Table 11 . The Registry of Toxic Effects of Chemical Substances recommends an exposure 1 imit for carbon monoxide of $40 \mathrm{mg} / \mathrm{m}^{3}$ (NIOSH 1991). WHC has not established a set of EPRG limits for carbon monoxide. The recommended exposure limit is a timeweighted average for a 10-hr work day during a 40-hr work week. The unmitigated and mitigated concentrations are with in the guidelines.

Table 11. Predicted Concentrations for Carbon Monoxide in Organic Fire Plume.

\begin{tabular}{|c|c|c|c|}
\hline Receptior. & (seorin: & 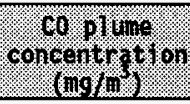 & 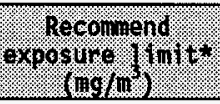 \\
\hline \multicolumn{4}{|c|}{ Unmitigated (No Berm) } \\
\hline Onsite & $3.03 \mathrm{E}-06$ & 2.32 & 40 \\
\hline Offsite & $1.50 \mathrm{E}-07$ & 0.12 & 40 \\
\hline \multicolumn{4}{|c|}{ Mitigated (With Berm) } \\
\hline Onsite & $5.49 \mathrm{E}-05$ & 1.62 & 40 \\
\hline Offsite & $1.54 \mathrm{E}-06$ & 0.04 & 40 \\
\hline
\end{tabular}

*NIOSH 1991.

By comparison, the maximum concentration at the alternate site boundary described in Section 5.1, which considers Highway 240 and the near side of the river, is $0.2 \mathrm{mg} / \mathrm{m}^{3}$ for the unmitigated case, and $0.04 \mathrm{mg} / \mathrm{m}^{3}$ for the mitigated case. 


\subsection{HYDROGEN EXPLOSION IN THE TANK HEADSPACE}

A hydrogen concentration of 10 vol\% is assumed at which a hydrogen deflagration occurs. To determine the heat of combustion (BTU), assuming $11,280 \mathrm{BTU} / \mathrm{m}^{3}\left(319.4 \mathrm{BTU} / \mathrm{ft}^{3}\right)$ (Marks' Handbook) at standard temperature and pressure (STP), requires a value for the hydrogen in the headspace to be determined. With $9,460 \mathrm{~L}(2,500 \mathrm{gal})$ of liquid, the headspace volume is $17,500 \mathrm{~L}-9,460 \mathrm{~L}=8,040 \mathrm{~L}(4,623 \mathrm{gal}-2,500 \mathrm{gal}=2,124 \mathrm{gal})$. With 10 vol\%, there are $804 \mathrm{~L}\left(0.804 \mathrm{~m}^{3}\right)$ of hydrogen. $804 \mathrm{~L}\left(0.804 \mathrm{~m}^{3}\right)$ of hydrogen equates to $2.3 \times 10^{6} \mathrm{cal}$ for the heat of combustion for the hydrogen. To calculate the grams of TNT equivalent, the heat of combustion for TNT of 4.773 Mjoule/kg (Thompson 1987) is used. This equates to $1,140 \mathrm{cal} / \mathrm{g}$. A value of $2.3 \times 10^{6} \mathrm{cal}$ equates to $2,018 \mathrm{~g}$ of TNT. To determine the amount of organic liquid released as respirable, the Steindler-Seefeldt correlation (Steindler \& Seefeldt 1980) is used. The Steindler-Seefeldt correlation developed a mass ratio (MR) with the MR being defined as the ratio of the mass of solid or liquid material at risk (MAR), to the mass of the TNT equivalent of the explosive. The configuration of the explosive material and the MAR examined by Steindler-Seefeldt was typically spherical or cylindrical with a height to diameter ratio of near one. The explosive was usually placed at the center with the material to be dispersed placed in the annular space surrounding. The experiments actually considered were only up to MRs of 15, although extrapolations are provided in the form of plots up to a MR of 400 . From the MRs provided, the amount of material made airborne 10 micron or smaller is provided. For this scenario, it is assumed the quantity of organic liquid is the lowest anticipated, or $9,460 \mathrm{~L}(2,500 \mathrm{gal})$. At $820 \mathrm{~g} / \mathrm{L}$, the total mass of the 1 iquid is $7.8 \times 10^{6} \mathrm{~g}$. The MR in this case becomes $7.8 \times 10^{6} \mathrm{~g} \div 2,018=$ 3,865 . Since the actual experimental work only went up to a MR of 15 , the more conservative value of 15 is used for the MR. Based upon the SteindlerSeefeldt correlation, for a MR of $15, \sim 0.07 \mathrm{~g}$ of material $/ \mathrm{g}$ of TNT equivalent, is released at 20 microns or less. The use of 20 microns is chosen to allow evaporation of the 1 iquid particles down to 10 micron while enroute to the receptors. If the equivalent of $2,018 \mathrm{~g}$ of TNT is released from the hydrogen detonation, $141 \mathrm{~g}$ of organic liquid would be released that is respirable. However, Thompson (1987) states that the "TNT-equivalent" for a unconfined flammable gas-air detonation seldom exceeds $10 \%$ of theoretical and recommends $10 \%$ be used for safety assessment purposes. Therefore, $202 \mathrm{~g}$ of TNT is assumed as the deflagration energy. With a MR of $0.07,14.1 \mathrm{~g}$ of liquid is released as respirable. Since the ${ }^{90} \mathrm{Sr}$ has a higher $\mathrm{DCF}$ than ${ }^{737} \mathrm{Cs}_{5}$, the bounding case of $707.87 \mathrm{Ci}$ of ${ }^{90} \mathrm{Sr}$ from Table 5 is assumed to be contained in the $9,460 \mathrm{~L}\left(7.8 \times 10^{6} \mathrm{~g}\right)$. Therefore, $14.1 \mathrm{~g} / 7.8 \times 10^{6} \mathrm{~g} \times 707.8 \mathrm{Ci}=0.00128$ $\mathrm{C} i$ of ${ }^{90} \mathrm{Sr}$ is released as respirable. The resultant $\mathrm{ARF}$ is $1.8 \times 10^{-6}$. This compares closely with the $1.1 \times 10^{-6}$ ARF recommended from DOE-HOBK-3010-94 (Section 3.2.2.2) for blast effects for a deflagration of a flammable vapor mixture over aqueous liquids. Using the relationship of:

$$
\text { Dose }=(C i) \times(X / Q) \times(B R) \times(D C F)
$$

and taking no credit for plume meander as this is a "puff" release, the consequences are:

$$
\begin{gathered}
{ }^{90} \mathrm{Sr} \text { onsite }=(.00128 \mathrm{Ci})\left(3.44 \mathrm{E}-02 \mathrm{~s} / \mathrm{m}^{3}\right)\left(3.3 \mathrm{E}-04 \mathrm{~m}^{3} / \mathrm{s}\right)(2.47 \mathrm{E}+05 \mathrm{rem} / \mathrm{C} \mathrm{i})= \\
3.59 \mathrm{E}-02 \mathrm{mSV}(3.59 \mathrm{E}-03 \mathrm{rem})
\end{gathered}
$$




$$
\begin{gathered}
{ }^{90} \mathrm{Sr} \text { offsite }=(.00128 \mathrm{Ci})\left(1.35 \mathrm{E}-05 \mathrm{~s} / \mathrm{m}^{3}\right)\left(3.3 \mathrm{E}-04 \mathrm{~m}^{3} / \mathrm{s}\right)(2.47 \mathrm{E}+05 \mathrm{rem} / \mathrm{Ci})= \\
1.41 \mathrm{E}-05 \mathrm{mSv}(1.41 \mathrm{E}-06 \mathrm{rem})
\end{gathered}
$$

By comparison, the maximum dose at the alternate site boundary described in Section 5.1, which considers Highway 240 and the near side of the river, is $1.98 \times 10^{-5} \mathrm{mSv}\left(1.98 \times 10^{-6} \mathrm{rem}\right)$.

It is highly likely that if a hydrogen explosion occurred, the organic liquid not immediately released would also burn, and the combined consequences for both the mitigated case (berm remains in place) and unmitigated case (berm not in place) from Table 9 are shown in Table 12. The combined consequences considers the explosion as a ground release while the burning of the organic takes credit for plume rise.

Table 12. Predicted Radiological Consequences For $\mathrm{H}_{2}$

\begin{tabular}{|c|c|c|}
\hline Receptor & isv $60 \mathrm{ran})$ & 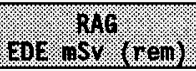 \\
\hline \multicolumn{3}{|c|}{ Unmitigated (No Berm) } \\
\hline Onsite & $\begin{array}{l}6.0 \mathrm{E}-02 \\
(6.0 \mathrm{E}-03) \\
\end{array}$ & $50(5)$ \\
\hline Offsite & $\begin{array}{l}6.8 \mathrm{E}-04 \\
(6.8 \mathrm{E}-05) \\
\end{array}$ & $5(0.5)$ \\
\hline \multicolumn{3}{|c|}{ Mitigated (With Berm) } \\
\hline Onsite & $\begin{array}{c}2.8 E-01 \\
(2.8 E-02) \\
\end{array}$ & 50 (5) \\
\hline Offsite & $\begin{array}{c}6.8 \mathrm{E}-03 \\
(6.8 \mathrm{E}-04)\end{array}$ & $5(0.5)$ \\
\hline
\end{tabular}
Explosion And Organic Fire.

By comparison, the maximum consequences at the alternate site boundary described in Section 5.1, which considers Highway 240 and the near side of the river, is $1.1 \times 10^{-3} \mathrm{mSv}\left(1.1 \times 10^{-4} \mathrm{rem}\right)$ for the unmitigated case, and $7.4 \mathrm{x}$ $10^{-3} \mathrm{mSv}\left(7.4 \times 10^{-4} \mathrm{rem}\right)$ for the mitigated case.

\subsection{SPILL OF ORGANIC FROM EXIERNAL TANK (RADIOLOGICAL CONSEQUENCES)}

This scenario examines the consequences from a spill of organic liquid from the tank and the resuspension of radionuclides in the liquid due to wind entrainment. The tank is assumed to contain its higher concentrations from Table 5. Since ${ }^{90} \mathrm{Sr}$ has the higher DCF, it is assumed that $707.87 \mathrm{Ci}$ of ${ }^{90} \mathrm{Sr}$ is present. DOE-HDBK-3010 (DOE 1994) provides recommended bounding suspension rates based upon experimental test conditions for aerodynamic entrainment and resuspension. For outdoors at 10 w wind speeds, a bounding airborne release rate (ARR) of $4.0 \times 10^{-7} / \mathrm{hr}$ is provided, while for wind speeds at $13.4 \mathrm{~m} / \mathrm{s}$ (30 $\mathrm{mph}$ ), a bounding ARR of $4.0 \times 10^{-6} / \mathrm{hr}$ is provided. Although the dispersion factors are higher for the lower wind velocities, the $4.0 \times 10^{-6} / \mathrm{hr}$ value is conservatively used. With $707.87 \mathrm{Ci}$ of ${ }^{90} \mathrm{Sr}$ contained within the organic liquid, in $8-h r$ the release made airborne is $707.87 \mathrm{Ci} \times 4.0 \times 10^{-6} / \mathrm{hr} \times 8-\mathrm{hr}$ $=2.27 \times 10^{-2} \mathrm{Ci}$ of ${ }^{90} \mathrm{Sr}$ released to the onsite receptor. For the offsite 
receptor who is assumed to remain in the plume for 24-hr, the release is $6.81-$ $02 \mathrm{Ci}$ of ${ }^{90} \mathrm{Sr}$. Since the release last longer than $1-\mathrm{hr}$, credit for plume meander may be taken and the doses are:

$$
\begin{gathered}
{ }^{90} \mathrm{Sr} \text { onsite }=(0.0227 \mathrm{Ci})\left(1.12 \mathrm{E}-02 \mathrm{~s} / \mathrm{m}^{3}\right)\left(3.3 \mathrm{E}-04 \mathrm{~m}^{3} / \mathrm{s}\right)(2.47 \mathrm{E}+05 \mathrm{rem} / \mathrm{Ci})= \\
2.07 \mathrm{E}-01 \mathrm{mSv}(2.07 \mathrm{E}-02 \mathrm{rem}) \\
{ }^{90} \mathrm{Sr} \text { offsite }=\left(\begin{array}{ll}
0.0681 \mathrm{Ci})\left(1.13 \mathrm{E}-05 \mathrm{~s} / \mathrm{m}^{3}\right)\left(3.3 \mathrm{E}-04 \mathrm{~m}^{3} / \mathrm{s}\right)(2.47 \mathrm{E}+05 \mathrm{rem} / \mathrm{C} \mathrm{i})= \\
6.27 \mathrm{E}-04 \mathrm{mSv}(6.27 \mathrm{E}-05 \mathrm{rem})
\end{array}\right.
\end{gathered}
$$

By comparison, the maximum dose at the alternate site boundary described in Section 5.1, which considers Highway 240 and the near side of the river, is $8.44 \times 10^{-4} \mathrm{mSv}\left(8.44 \times 10^{-5} \mathrm{rem}\right)$.

\subsection{SPILL OF ORGANIC FROM EXTERNAL TANK (TOXICOLOGICAL CONSEQUENCES)}

This is a similar scenario, but the toxic consequences due to the TBP is examined. The organic liquid contains approximately $10 \% \mathrm{TBP}$, which is considered a toxic chemical. The emergency response planning guidelines (ERPGs) for TBP are: ERPG-1 $=3 \mathrm{mg} / \mathrm{m}^{3}$, ERPG-2 $=15 \mathrm{mg} / \mathrm{m}^{3}$, and $E R P G-3=50$ $\mathrm{mg} / \mathrm{m}^{3}$. The PEL-TWA value is $2.5 \mathrm{mg} / \mathrm{m}^{3}$. With an airborne release rate (ARR) of $4.0 \times 10^{-6} / \mathrm{hr}\left(1.1 \times 10^{-9} / \mathrm{s}\right)$ the equivalent of $15,140 \mathrm{~L} \times 820 \mathrm{~g} / \mathrm{L} \times 1.1 \times$ $10^{-9} / \mathrm{s}=1.37 \times 10^{-2} \mathrm{~g} / \mathrm{s}(13.7 \mathrm{mg} / \mathrm{s})$ of organic 1 iquid is released. The density of TBP is $0.98 \mathrm{~g} / \mathrm{cm}^{3}$ while the organic liquid has a density of 0.82 $\mathrm{g} / \mathrm{cm}^{3}$. With approximately $10 \%$ by volume of the organic liquid being TBP, on a weight percentage, the TBP represents about $10 \% \times .98 / .82=12 \%$ of the organic 1iquid. Therefore the release rate of the TBP is approximately $12 \% \times 13.7 \mathrm{mg} / \mathrm{s}$ $=1.6 \mathrm{mg} / \mathrm{s}$. With an onsite dispersion factor of $3.44 \times 10^{-2} \mathrm{~s} / \mathrm{m}^{3}$ (not taking credit for plume meander for toxic releases), the onsite concentration is $0.055 \mathrm{mg} / \mathrm{m}^{3}$. The offsite consequences are approximately 1000 times 1 ess. Both onsite and offsite consequences are well below the risk acceptance guidel ines.

\subsection{CONTROLS}

A11 accidents analyzed, even at the higher radionuclide concentrations of Table 5, result in all onsite and offsite consequences well below the risk acceptance guidelines, even at a probability of 1 for each event. Furthermore, there is no requirement for any safety-class or safetysignificant structure, system, or component (SSC).

\subsection{RADIOACTIVE INVENTORIES}

Since no credit is taken for the administrative or engineered barriers in the above calculations, the only Control required for storage of the organic liquid is to ensure the radionuclide concentrations are below the 5 rem calculations in Appendix $A$ and shown in Table 5 prior to placing the tank onto the concrete pad. The allowable ${ }^{90} \mathrm{Sr}$ and ${ }^{137} \mathrm{Cs}$ concentrations still provide a large margin of safety, and are reproduced as Table 13. 
Table 13. Maximum ${ }^{90} \mathrm{Sr}$ and ${ }^{137} \mathrm{Cs}$ Quantities (Ci) Prior To Placement of Tank Onto Concrete Pad.

\begin{tabular}{|c|c|c|c|c|c|}
\hline \% $1(1 / 1)$ & 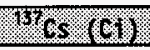 & \% & 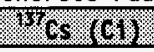 & 10. 1616 & 156. \\
\hline 707.87 & 0 & 707.45 & 2.50 & $707 \ldots 03$ & 5.00 \\
\hline 707.83 & 0.25 & 707.40 & 2.75 & 706.98 & 5.25 \\
\hline 707.78 & 0.50 & 707.36 & 3.00 & 706.94 & 5.50 \\
\hline 707.74 & 0.75 & 707.32 & 3.25 & 706.90 & 5.75 \\
\hline 707.70 & 1.00 & 707.28 & 3.50 & 706.86 & 6.00 \\
\hline 707.66 & 1.25 & 707.24 & 3.75 & 706.81 & 6.25 \\
\hline 707.61 & 1.50 & 707.19 & 4.00 & 706.77 & 6.50 \\
\hline 707.57 & 1.75 & 707.15 & 4.25 & 706.73 & 6.75 \\
\hline 707.53 & 2.00 & 707.11 & 4.50 & 706.69 & 7.00 \\
\hline 707.49 & 2.25 & 707.07 & 4.75 & & \\
\hline
\end{tabular}

\subsection{TRANSFER FROM PRIMARY TO SPARE TANK}

Transfer of the organic liquid from the primary tank to the spare tank, as well as transfer back to the primary tank, is permitted provided the pump pressure does not exceed $0.70 \mathrm{MPa}(100 \mathrm{psi})$ and the same type of flexible hose is used as for the transfer from B Plant to the external tank located on the flat-bed truck, as analyzed in the Safety Assessment For Removal of Organic Liquids From B Plant (WHC 1996a).

\subsection{REFERENCES}

Clewell, 1983, A Simple Formula For Estimating Source Strengths From Spills of Toxic Liquids, ESL-TR-83-03, Engineering \& Services Laboratory, Air Force Engineering \& Services Center, Tyndall Air Force Base, Florida.

Crippen, M. D., 1993, Barometric Pressure Variations, WHC-EP-0651, Westinghouse Hanford Company, Richland, Washington.

DOE, 1994, Airborne Release Fractions/Rates and Respirable Fractions For Nonreactor Nuclear Facilities, DOE-HDBK-3010-94, U.S. Department of Energy, Washington, D.C.

EPA, 1988, Limiting Values of Radionuclide Intake And Air Concentration and Dose Conversion Factors For Inhalation, Submersion, And Ingestion, EPA520/1-88-020, U.S. Environmental Protection Agency, Washington, D.C.

Fogiel, M., Ed., 1973, Pollution Control Technology, Research and Education Association, New York, New York.

GE, 1989, Nuclides and Isotopes, Fourteenth Edition, General Electric Company, San Jose, California. 
Himes, D. A, 1996, Atmospheric Dispersion Parameters for B Plant Organic Liquid Storage Fire Scenarios, Draft WHC-SD-WM-CN-064, Westinghouse Hanford Company, Richland, Washington.

Marks' Handbook, Standard Handbook for Mechanical Engineers, Eighth Edition, McGraw-Hill Book Company, New York, New York.

NIOSH, 1991, Registry of Toxic Effects of Chemical Substances, U.S. Department of Health and Human Services, National Institute for Occupational Safety and Health, Washington, D.C.

RHO, 1986, Hydrogen Control in the Handling, Shipping and Storage of Wet Radioactive Waste, RHO-WM-EV-9 Rev. IP, Rockwe11 International, Rockwell Hanford Operations, Richland, Washington.

Steindler, M.J. and W.H. Seefeldt, 1980, A Method for Estimating the Challenge to an Air Cleaning System, Proceedings of the 16th DOE Air Cleaning Conference (M.W. First, Ed.), Harvard Air Cleaning Laboratory, Boston, Massachusetts.

Thompson, 1987, Engineering Safety Assessment, National Nuclear Corporation Ltd., Knutsford, Cheshire, Essex, England.

WHC, 1996a, Safety Assessment For Removal of Organic Liquids From B Plant, WHC-SD-WM-CN-017, Westinghouse Hanford Company, Richland, Washington.

WHC, 1996b, Safety Analysis Manual, WHC-CM-4-46, Release 18, Westinghouse Hanford Company, Richland, Washington.

WHC, 1996C, B Plant Interim Safety Basis Accident Analysis, WHC-SD-WM-SARR030, Westinghouse Hanford Company, Richland, Washington. 
HNF-SD-OPS-SAD-001, Rev. 0

APPENDIX A

MATHCAD CALCULATIONS

A-1 
HNF-SD-0PS-SAD-001, Rev. 0

This page intentionally left blank.

A-2 


\section{USQ Evaluation of Organic Liquid Storage Outside of B Plant Back Calculation of ${ }^{137} \mathrm{Cs}$ and ${ }^{90} \mathrm{Sr}$ Curie Concentrations to Define Safety Envelope For Fire Scenarios}

\footnotetext{
Mathcad computer software version 5.0 was used to perform these calculations. Mathcad is a trademark of MathSoft, Inc. The dose conversion factors (DCFs) are from EPA (1988). The ground release dispersion factors (X/Qs) and airborne release fractions (ARFs) are from B Plant Interim Safety Basis (ISB) Accident Analysis. With a berm in place around the tank, the burn time is greater than 1-hr and credit for plume meander may be taken. Without a berm, the spill area is much greater and the burn time is less than 1-hr and in this case, credit for plume meander cannot be taken. Both cases are examined. The criterion of 5 rem EDE onsite radiological consequences to the $100 \mathrm{~m}$ receptor is used, which is valid even for "anticipated" events. Since ${ }^{90} \mathrm{Y}$ is in equilibrium with the ${ }^{90} \mathrm{Sr}$, the DCF for ${ }^{90} \mathrm{Sr}$ includes that of ${ }^{90} \mathrm{Y}$. The ARFs are taken from the B Plant ISB and for a release from a flammable liquid, are 0.01 for ${ }^{137} \mathrm{Cs}$ and 0.0077 for ${ }^{90} \mathrm{Sr}$. The dose calculations are derived using the following equation:

Dose $=(\mathrm{Ci}) \times($ XoverQ $) \times(\mathrm{BR}) \times(\mathrm{DCF})$

where: $\quad \mathrm{Ci} \quad=$ amount of curies release as respirable $=\mathrm{Ci}$ available $\times \mathrm{ARF}$

XoverQ = dispersion factor (units of $\mathrm{s} / \mathrm{m}^{3}$ )

$\mathrm{BR} \quad=$ breathing rate $\left(3.3 \mathrm{E}-04 \mathrm{~m}^{3} / \mathrm{s}\right)$

DCF = dose conversion factor

$=3.19 \mathrm{E}+04 \mathrm{rem} / \mathrm{Ci}$ for ${ }^{137} \mathrm{Cs}$ or (DCF137Cs)

$=2.47 \mathrm{E}+05 \mathrm{rem} / \mathrm{Ci}$ for ${ }^{90} \mathrm{Sr}$ (includes ${ }^{90} \mathrm{Y}$ ) or (DCF90Sr)

ARF = airborne release fraction

$=0.01$ for ${ }^{137} \mathrm{Cs}$

$=0.0077$ for ${ }^{90} \mathrm{Sr}$
}

Combining the above, the onsite dose can be calculated as:

Doseon $=($ Ci137Cs $)(0.01)($ XoverQon $)(B R)(D C F C s)+(C i 90 S r)(0.0077)($ XoverQon $)(B R)(D C F S r)$

Definition of Terms For Mathcad Use:

Doseon : $5 \cdot$ rem

BR : $3.3 \cdot 10^{04} \mathrm{~m}^{3} / \mathrm{s}$

DCF90Sr : $2.46 \cdot 10^{05} \cdot \stackrel{\text { rem }}{\mathrm{Ci}}$
XoverQon : $3.44 \cdot 10^{02} \mathrm{~s} / \mathrm{m}^{3}$ (no plume meander)

XoverQonpm $\quad 1.13 \cdot 10^{02} \mathrm{~s} / \mathrm{m}^{3}$ (with plume meander)

DCF137Cs $\quad 3.19 \cdot 10^{04} \cdot \frac{\mathrm{rem}}{\mathrm{Ci}}$ 
HNF-SD-OPS-SAD-001, Rev. 0

Rearranging terms and solving for $\mathrm{CiSr} 90$ as a function of $\mathrm{CiCs} 137$ :

Ci90Sr(Ci137Cs) Doseon $\frac{.01 \cdot C i 137 \text { Cs-XoverQon-BR-DCF137Cs }}{.0077 \cdot \text { XoverQon-BR.DCF90Sr }}$

$\mathrm{Ci} 137 \mathrm{Cs} \quad 0 \cdot \mathrm{Ci}, 25 \cdot \mathrm{Ci} . .7 \cdot \mathrm{Ci}$ (Defines range for ${ }^{137} \mathrm{Cs}$ and steps to be evaluated)

Ci90SR(Ci137Cs)

Doseon $\quad 01 \cdot \mathrm{Ci} 137 \mathrm{Cs} \cdot$ XoverQon $\cdot \mathrm{BR} \cdot \mathrm{DCF} 137 \mathrm{Cs}$ .0077. XoverQon'BR.DCF90Sr

\begin{tabular}{|c|c|c|}
\hline Ci137C & $\mathrm{Ci} 90 \mathrm{Sr}(\mathrm{Ci} 137 \mathrm{Cs})$ & \\
\hline 0 & 232.53 & $\mathrm{Ci} \cdot \mathrm{I}$ \\
\hline 0.25 & 232.48 & rem 1 \\
\hline 0.5 & 232.44 & \\
\hline 0.75 & 232.4 & \\
\hline$T$ & 232.36 & \\
\hline 1.25 & 232.32 & \\
\hline 1.5 & 232.27 & \\
\hline 1.75 & 232.23 & \\
\hline 2 & 232.19 & \\
\hline 2.25 & 232.15 & \\
\hline 2.5 & 232.11 & \\
\hline 2.75 & 232.06 & \\
\hline 3 & 232.02 & \\
\hline 3.25 & 231.98 & \\
\hline 3.5 & 231.94 & \\
\hline 3.75 & \begin{tabular}{|l|l|}
231.89 \\
\end{tabular} & \\
\hline 4 & 231.85 & \\
\hline 4.25 & 231.81 & \\
\hline 4.5 & 231.77 & \\
\hline 4.75 & 231.73 & \\
\hline 5 & 231.68 & \\
\hline 5.25 & 231.64 & \\
\hline 5.5 & 231.6 & \\
\hline 5.75 & 231.56 & \\
\hline 6 & 231.52 & \\
\hline 6.25 & \begin{tabular}{|l|}
231.47 \\
\end{tabular} & \\
\hline 6.5 & 231.43 & \\
\hline 6.75 & 231.39 & \\
\hline & 231.35 & \\
\hline
\end{tabular}


HNF-SD-OPS-SAD-001, Rev. 0

In a similar way, the calculations are performed assuming the berm is in place and therefore credit for plume meander is taken.

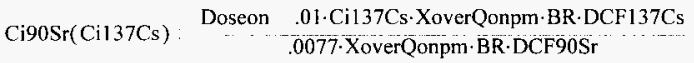

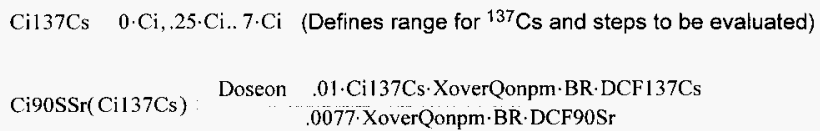

\begin{tabular}{|c|c|}
\hline $\mathrm{Ci} 137 \mathrm{C}$ & $\mathrm{Ci} 90 \mathrm{Sr}(0$ \\
\hline 0 & 707.87 \\
\hline 0.25 & 707.83 \\
\hline 0.5 & 707.78 \\
\hline 0.75 & 707.74 \\
\hline$T$ & 707.7 \\
\hline 1.25 & 707.66 \\
\hline 1.5 & 707.61 \\
\hline 1.75 & 707.57 \\
\hline 2 & 707.53 \\
\hline 2.25 & 707.49 \\
\hline 2.5 & 707.45 \\
\hline 2.75 & 707.4 \\
\hline 3 & 707.36 \\
\hline 3.25 & 707.32 \\
\hline 3.5 & 707.28 \\
\hline 3.75 & 707.24 \\
\hline 4 & 707.19 \\
\hline 4.25 & 707.15 \\
\hline 4.5 & 707.11 \\
\hline 4.75 & 707.07 \\
\hline 5 & 707.03 \\
\hline 5.25 & 706.98 \\
\hline 5.5 & 706.94 \\
\hline 5.75 & 706.9 \\
\hline 6 & 706.86 \\
\hline 6.25 & 706.81 \\
\hline 6.5 & 706.77 \\
\hline 6.75 & 706.73 \\
\hline & 706.69 \\
\hline
\end{tabular}


HNF-SD-0PS-SAD-001, Rev. 0

This page intentionally left blank. 
HNF-SD-OPS-SAD-001, Rev. 0

\section{APPENDIX B \\ PRELIMINARY HAZARDS ANALYSIS (PHA) PARTICIPANTS}


HNF-SD-OPS-SAD-001, Rev. 0

This page intentionally left blank. 
List A. B Plant ISB PHA Participants (7/18/96)

\begin{tabular}{|l|l|}
\hline \multicolumn{1}{|c|}{ Name } & \multicolumn{1}{c|}{ Organization } \\
\hline Steve Chalk & $\begin{array}{l}\text { FDNW/SAR Engineering } \\
\text { Services }\end{array}$ \\
\hline Kaleem U1lah & $\begin{array}{l}\text { B\&W Hanford Co./B-Plant/ } \\
\text { Safety }\end{array}$ \\
\hline Bruce Gilkeson & FDNW/Projects \\
\hline Monica Serkowski & B\&W Hanford Co./B-Plant \\
\hline Scott Ellingson & FDNW/Engineering \\
\hline Rex Bendixsen & FDNW/Specialty Engineering \\
\hline John Joyce & LATA \\
\hline Evan Hafla & B\&W Hanford Co./B-Plant \\
\hline Fred Heard & NHC \\
\hline Kimberly Williams & DOE/TPD/B-Plant/WESF \\
\hline Judith Siemer & LATA \\
\hline
\end{tabular}

List B. B Plant ISB PHA Participants (7/22/96)

\begin{tabular}{|l|l|}
\hline \multicolumn{1}{|c|}{ Name } & \multicolumn{1}{|c|}{ Organization } \\
\hline Ron Kidder & $\begin{array}{l}\text { FDNW/SAR Engineering } \\
\text { Services }\end{array}$ \\
\hline Dewey Robbins & B\&W Hanford Co./B Plant \\
\hline Bruce Gilkeson & FDNW/Projects \\
\hline Evan Hafla & B\&W Hanford Co./B-Plant \\
\hline Monica Serkowski & B\&W/B-Plant \\
\hline Kim Beecher & GSSC \\
\hline Scott Ellingson & FDNW Engineering \\
\hline John Joyce & LATA \\
\hline Bryan Jackson & FDNW/B-Plant \\
\hline Rex Bendixson & FDNW/Specialty Engineering \\
\hline Kimberly Williams & DOE/TPD/B-Plant/WESF \\
\hline Judith Siemer & LATA \\
\hline
\end{tabular}


HNF-SD-OPS-SAD-001, Rev. 0

This page intentionally left blank. 


\section{HNF-SD-OPS-SAD -001, REV.O}

\section{CHECKLIST FOR PEER REVIEW}

Document Reviewed: C. H. Huang, " SAFETY ASSESSMENT FOR STORAGE OF ORGANIC LIQUIDS ADJACENT TO B PLANT," February 11, 1997.

Scope of Review: SECTION 4.3

Yes No NA

[ ] [ ] [x] * Previous reviews complete and cover analysis, up to scope of this review, with no gaps.

[X] [ ] [ ] Problem completely defined.

[x] [ ] [ ] Accident scenarios developed in a clear and logical manner.

[x] [ ] [ ]

Necessary assumptions explicitly stated and supported.

Computer codes and data files documented.

Data used in calculations explicitly stated in document.

$[x][][]$

Data checked for consistency with original source information as applicable.

[ ] [ ] [X] Mathematical derivations checked including dimensional consistency of results.

[X] [ ] [ ] Models appropriate and used within range of validity or use outside range of established validity justified.

[X] [ ] [ ] Hand calculations checked for errors. Spreadsheet results should be treated exactly the same as hand calculations.

[ ] [ ] [X] Software input correct and consistent with document reviewed.

[ ] [ ] [X] Software output consistent with input and with results reported in document reviewed.

[X] [ ] [ ] Limits/criteria/guidelines applied to analysis results are appropriate and referenced. Limits/criteria/guidelines checked against references.

[X] [ ] [ ] Safety margins consistent with good engineering practices.

[X] [ ] [ ] Conclusions consistent with analytical results and applicable limits.

[X] [ ] [ ] Results and conclusions address all points required in the problem statement.

[ ] [ ] $[X]$ Format consistent with appropriate NRC Regulatory Guide or other standards

[ ] $[X]$ * Review calculations, comments, and/or notes are attached.

[X] [ ] [ ] Document approved.

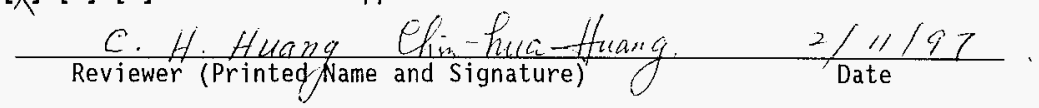


HNF-SD-OPS-SAD-OOI, REV.O

\section{CHECKLIST FOR PEER REVIEW}

Document Reviewed: WHC-OPS-SAD-001, Safety Assessment For Storage of Organic Liquids Adjacent to B Plant

Scope of Review: Pages 1 through 29

Yes No NA

[ ] [ ] [x] * Previous reviews complete and cover analysis, up to scope of this review, with no gaps.

[x] [ ] [ ] Problem completely defined.

[x] [ ] [ ] Accident scenarios developed in a clear and logical manner.

$[x][$ [ ] ]

[x] [ ] [ ]

$[x][]\left[\begin{array}{ll}0 \\ {[}\end{array}\right]$

Necessary assumptions explicitly stated and supported.

Computer codes and data files documented.

Data used in calculations explicitly stated in document.

Data checked for consistency with original source information as applicable.

[x] [ ] [ ] Mathematical derivations checked including dimensional consistency of results.

[x] [ ] [ ] Models appropriate and used within range of validity or use outside range of established validity justified.

[x] [ ] [ ] Hand calculations checked for errors. Spreadsheet results should be treated exactly the same as hand calculations.

[ ] []$[\mathrm{x}]$ Software input correct and consistent with document reviewed.

Software output consistent with input and with results reported in document reviewed.

Limits/criteria/guidelines applied to analysis results are appropriate and referenced. Limits/criteria/guidelines checked against references.

[x] [ ] [ ] Safety margins consistent with good engineering practices.

$[x][$ [ [ ] Conclusions consistent with analytical results and applicable limits.

[x] [ ] [ ] Results and conclusions address all points required in the problem statement.

[x] [ ] [ ] Format consistent with appropriate NRC Regulatory Guide or other standards

[ ] [x] * Review calculations, comments, and/or notes are attached.

\section{[x ] [ ] [ ] Document approved.}

John E. Kelly Qhonekell. Reviewer (Printed Name and Signatúre) Date

* Any calculations, comments, or notes generated as part of this review should be signed, dated and attached to this checklist. Such material should be labeled and recorded in such a manner as to be intelligible to a technically qualified third party. 


\section{DISTRIBUTION SHEET}

\begin{tabular}{|c|c|c|c|c|c|}
\hline \multirow{2}{*}{$\begin{array}{l}\text { To } \\
\text { Distribution }\end{array}$} & \multirow{2}{*}{\multicolumn{3}{|c|}{$\begin{array}{l}\text { From } \\
\text { SAR Engineering Services }\end{array}$}} & \multicolumn{2}{|c|}{ Page 1 of 1} \\
\hline & & & & \multicolumn{2}{|c|}{ Date $2 / 11 / 97$} \\
\hline \multicolumn{4}{|l|}{ Project Title/Work Order } & \multicolumn{2}{|c|}{ EDT No. 616283} \\
\hline \multicolumn{4}{|c|}{$\begin{array}{l}\text { Safety Assessment for Storage of Organic Liquids Adjacent to } \\
\text { B Plant }\end{array}$} & \multicolumn{2}{|c|}{ ECN No. N/A } \\
\hline Name & MSIN & $\begin{array}{c}\text { Text } \\
\text { With All } \\
\text { Attach. }\end{array}$ & Text Only & $\begin{array}{l}\text { Attach./ } \\
\text { Appendix } \\
\text { Only }\end{array}$ & $\begin{array}{l}\text { EDT/ECN } \\
\text { Only }\end{array}$ \\
\hline $\begin{array}{l}\text { Central Files (original }+2 \text { copies) } \\
\text { Chalk, S.E. } \\
\text { Docket Files (2 copies) } \\
\text { Dodd, E.N. Jr. } \\
\text { Gray, B.J. } \\
\text { Hafla, E.R. } \\
\text { Hill, M.A. } \\
\text { Johnson, L.E. } \\
\text { Rau, A.B. } \\
\text { Robbins, E.D. } \\
\text { Roege, P.E. }\end{array}$ & $\begin{array}{l}\text { A3-88 } \\
\text { A2-25 } \\
\text { B1-17 } \\
\text { S4-66 } \\
\text { S6-81 } \\
\text { S6-60 } \\
\text { S4-66 } \\
\text { A2- } 25 \\
\text { A2-25 } \\
\text { S6-59 } \\
\text { S4-66 }\end{array}$ & $\begin{array}{l}x \\
x \\
x \\
x \\
x \\
x \\
x \\
x\end{array}$ & & & $\begin{array}{l}x \\
x\end{array}$ \\
\hline
\end{tabular}

